\title{
De last van de overlevering : gender en de herinneringscultuur in de wetenschap
}

Citation for published version (APA):

Bosch, M. (2007). De last van de overlevering : gender en de herinneringscultuur in de wetenschap. Maastricht University. https://doi.org/10.26481/spe.20071004mb

Document status and date:

Published: 04/10/2007

DOI:

10.26481/spe.20071004mb

Document Version:

Publisher's PDF, also known as Version of record

\section{Please check the document version of this publication:}

- A submitted manuscript is the version of the article upon submission and before peer-review. There can be important differences between the submitted version and the official published version of record.

People interested in the research are advised to contact the author for the final version of the publication, or visit the DOI to the publisher's website.

- The final author version and the galley proof are versions of the publication after peer review.

- The final published version features the final layout of the paper including the volume, issue and page numbers.

Link to publication

\footnotetext{
General rights rights.

- You may freely distribute the URL identifying the publication in the public portal. please follow below link for the End User Agreement:

www.umlib.nl/taverne-license

Take down policy

If you believe that this document breaches copyright please contact us at:

repository@maastrichtuniversity.nl

providing details and we will investigate your claim.
}

Copyright and moral rights for the publications made accessible in the public portal are retained by the authors and/or other copyright owners and it is a condition of accessing publications that users recognise and abide by the legal requirements associated with these

- Users may download and print one copy of any publication from the public portal for the purpose of private study or research.

- You may not further distribute the material or use it for any profit-making activity or commercial gain

If the publication is distributed under the terms of Article $25 \mathrm{fa}$ of the Dutch Copyright Act, indicated by the "Taverne" license above, 


\section{De last van de overlevering}

Gender en de herinneringscultuur in de wetenschap 


\section{Colofon}

Tekening omslag: 'March of the University Women', door Paula Rooseboom IIAV-Amsterdam, Archief Johanna Westerdijk

Ontwerp en print: Océ Business Services, Maastricht

ISBN: 978-90-5681-269-0

NUR: 612

Alle rechten voorbehouden. Niets uit deze uitgave mag worden verveelvoudigd, opgeslagen in een geautomatiseerd gegevensbestand of openbaar gemaakt worden, zonder voorafgaande schriftelijke toestemming van de auteur of uitgever. 


\section{De last van de overlevering}

Gender en de herinneringscultuur in de wetenschap

Oratie

in verkorte vorm uitgesproken bij de aanvaarding van het ambt van bijzonder hoogleraar vanwege de Stichting Wetenschapsbeoefening UM, met de leeropdracht 'Gender en Wetenschap' aan de Universiteit Maastricht, op 4 oktober 2007 in de St. Janskerk

door

Mineke Bosch

Universiteit Maastricht 

Mijnheer de Rector Magnificus, mijnheer de Decaan, lieve familie, vriendinnen en vrienden, zeer geachte dames en heren

Ter gelegenheid van het vierde congres van de International Federation of University Women (IFUW) in 1926 in Amsterdam, zette Johanna Westerdijk, de eerste vrouwelijke hoogleraar in Nederland, samen met anderen, een geestige liederencyclus met bijpassende plaatjes in elkaar. Onderwerp was The Origin of the University Women, een oorsprongsmythe van de eigentijdse 'gestudeerde vrouwen', die zich sinds enkele jaren in een nationale en een internationale organisatie hadden verenigd. De teksten waren afwisselend in het Frans, Duits, Engels, en gemaakt op de wijs van internationaal befaamde liederen en liedjes.

Oermoeder van Westerdijks genealogie van de geleerde vrouw is Lilith, die volgens de Joodse overlevering net als Adam geschapen was uit leem en daarom ook zijn gelijke wilde zijn; ${ }^{2}$ dan volgt Minerva, de godin van de wijsheid, met in haar kielzog de krijgslustige amazones; in het gezelschap van de femmes savantes bevinden zich de Nederlandse geleerde Anna Maria van Schurman en de dichteres Maria Tesselschade. Als laatste volgt Andrea Novella, de Italiaanse die volgens Christine de Pisan in Het boek van de stad der vrouwen (1405) regelmatig haar vader, die hoogleraar was aan de universiteit van Bologna, verving en college gaf, maar wel vanachter een gordijn. ${ }^{3}$ Tegenover dit illustere gezelschap staan de 'vrouwtjes', die hun hoop op mannen vestigden: Eva, die in Liliths plaats kwam nadat die het paradijs achter zich had gelaten, Penelope, die zich wachtend op Odysseus listig de minnaars van het lijf hield, de mooie mannenverleidster Cleopatra, Vesta, de hoedster van de huiselijke haard, en tenslotte Gretchen aan haar spinnewiel: 'Binn so dumm, lieber Heinrich/ Binn unwissend und klein/ Möchte aber doch sicher/ Deine Herzliebste sein.' Voordat het slotlied 'March of the University Women' inzet, krijgt Adam nog een keer de gelegenheid zijn respect voor de Liliths der aarde te betuigen en de strijdbijl te begraven.

Getuige dit lied was wat de dochters van Lilith verbond niet alleen kennis, maar ook hun onafhankelijkheid van mannen. Dat Westerdijk haar vele vrouwelijke assistenten vaak op hilarische wijze opvoedde in de kunst van het ongehuwde bestaan heb ik elders met veel plezier uit de doeken gedaan. ${ }^{4}$ Ook werd door hen veelvuldig de wetenschap in haar meer aardse gedaante te kijk gezet op deftige internationale 
congressen en bij andere feestelijkheden. Ik herinner mij nog goed hoe wij op een van onze speurtochten naar archieven van vrouwen deze vrolijke schat op de grote stoffige zolder van het Willie Commelin Scholten Laboratorium ontdekten. 5 Dat bepaalde in zekere zin ook mijn lot. Want hoewel ik toen nog opging in de internationale vrouwenkie srechtbeweging, en ook dat onderwerp mij is blijven boeien getuige mijn biografie van Aletta Jacobs, werd mijn belangstelling voor het onderwerp vrouwen, gender en wetenschap daar zo niet geboren, dan toch versterkt. 6

Maar terwijl in de liederenshow de ongehuwde staat als een voordeel werd bezongen, sprak het officiële gedeelte van het congres van de IFUW een heel andere taal: voorzitster Virginia Gildersleeve, dean van Barnard College in New York, had het in haar openingstoespraak helemaal niet over het afzweren van het huwelijk, maar juist over de verzoening van huwelijk en carrière als de belangrijkste opgave voor de vereniging: 'The normal university or professional woman is not born to be celibate, childless and homeless.'7 Deze tegenstrijdigheid in het denken over het huwelijk is geen gevolg van de innerlijke gespletenheid van deze groep vrouwen, maar van het dilemma dat vrouwelijke wetenschappers zo lang gevangen hield: als (meestal ongehuwde) wetenschappers waren zij uitzonderingen onder de vrouwen, en als vrouwen waren zij uitzonderingen onder de (meestal gehuwde) wetenschappers. Geconfronteerd met de vraag, vaak ook het verwijt, van de grote uitval van vrouwelijke professionals, bij een cultuur die het werken van vrouwen in hogere beroepen aan alle kanten ontmoedigde en een wetgeving die de arbeid van gehuwde vrouwen in overheidsdienst in vele landen zelfs verbood, moesten de vrouwen gedurende de gehele twintigste eeuw laveren tussen Skylla en Charibdis: tussen enerzijds laten zien dat vrouwen (als zij maar ongehuwd bleven) heus wel in staat waren tot wetenschappelijk werk, en anderzijds aantonen dat vrouwen wel degelijk nog huwden ook al hadden zij gestudeerd.

Voor Westerdijk was dat niet anders dan voor Gildersleeve. In een door haar ondertekend memorandum ten behoeve van een 'Volkenbondrapport over de Status van Vrouwen' in 1935 werd ter verklaring van het geringe aantal vrouwelijke hoogleraren in de wereld zelfs de niet mis te verstane (statistische) term 'marriage mortality' ingezet: de gedwongen uitval of symbolische dood door huwelijk. Maar de betrokken vrouwen wisten ook toen al dat niet-huwen op zich geen 
oplossing was gezien de gehele formulering: 'The percentage of women on the teaching staff [of universities] is low, a fact by no means wholly accounted for by the greater "marriage mortality" among women.'8

Hoewel er inmiddels veel is veranderd, laten zich nog steeds talloze sporen van vroeger traceren. Zo verklaarde de microbioloog Nancy Hopkins, initiatiefnemer van een rapport over vrouwelijke hoogleraren aan het prestigieuze Massachusetts Institute of Technology (MIT) in de documentaire The Mind Has No Sex dat zij als jonge vrouw in de jaren zestig had besloten om niet te trouwen, maar dat dat lang niet alle problemen voor haar als wetenschapper had opgelost.9 In ongeveer dezelfde periode besloot de begaafde natuurwetenschapper Anneke Levelt Sengers Nederland te verruilen voor de Verenigde Staten, omdat hier alle deuren voor haar getrouwde neus dichtsloegen. In Amerika ontwikkelde zij zich tot een topwetenschapper op het gebied van stoom. ${ }^{10}$

Tegenwoordig betekent het huwelijk of het krijgen van kinderen niet zondermeer een diskwalificatie door ontslag (of gedwongen emigratie) van de vrouwelijke wetenschapper. Dat betekent niet dat het privéleven vanvrouwen onbetekenend isgeworden:geleerde moederszijn nogsteeds meer uitzondering dan regel in de wetenschap." Ook is de vraag 'waarom zijn er zo weinig vrouwelijke hoogleraren?' nog steeds uitermate actueel. Dezelfde vraag kan worden gesteld met betrekking tot de vrouwelijke leden van colleges van bestuur, vrouwelijke decanen, vrouwelijke leiders van onderzoekscholen en grote Europese onderzoeksprojecten. Evenals de aanpalende kwestie: waarom gaat de integratie van vrouwen in het wetenschappelijke domein zo verschrikkelijk langzaam? Veel langzamer nog dan bijvoorbeeld in de rechterlijke macht of in de politiek?

In deze openbare les wil ik $u$ eerst een indruk geven van het onderzoeksveld dat in de jaren zestig en zeventig van de vorige eeuw werd ontsloten als onderdeel van de grote sociale veranderingen die werden ingeluid door de tweede feministische golf. Alice Rossi wierp in 1965 de vraag 'Women in Science: Why so Few?' op tijdens een congres op het prestigieuze Massachusetts Institute of Technology (MIT). Die lezing werd het startschot voor het hele veld van onderzoek dat in mijn leerstoel wordt samengevat onder de noemer 'Gender and Science'.12 


\section{WAAROM ZO WEINIG?}

\section{Traditionele verklaringen}

Voor ik u mijn eigen antwoord ga voorleggen, herhaal ik nog eens wat de traditionele verklaringen zijn voor de relatief geringe aanwezigheid van vrouwen in topposities in de wetenschap. De eerste is dat 'er nu eenmaal aangeboren, biologische en essentiële verschillen zijn'. Deze uitleg noemde de Amerikaanse wiskundige Ben A. Barres vorig jaar in het belangrijke tijdschrift Nature de 'Larry Summers Hypothese', naar de toenmalige president van Harvard. ${ }^{33}$ Deze had in februari 2005, tijdens een bijeenkomst over diversiteit in de wetenschappen, gemeend hieruit tot zijn grote spijt het achterblijven van vrouwen in de natuurwetenschappen te moeten verklaren. ${ }^{14}$ Dat leidde tot wereldwijd protest onder aanvoering van topwetenschappers, onder wie opnieuw Nancy Hopkins, die in de zaal zat toen Summers zijn uitspraak deed. ${ }^{15}$ Summers schaarde zich met zijn opmerking in de lange rij van vooral mannelijke wetenschappers die in de negentiende en twintigste eeuw vergelijkbare theses de lucht in slingerden. Maar niet alleen is er nooit sluitend bewijs geleverd voor de (gemiddeld) mindere intellectuele vermogens van vrouwen ten opzichte van mannen (en de prestaties van studenten wijzen op het tegendeel), ook is nooit aangetoond dat er specifiek mannelijke karaktereigenschappen, genen of hormoonspiegels bestaan die hun in de intellectuele competitie onbetwist voorrang geven.

Wel is door wetenschappers als de evolutionair-bioloog Stephen Jay Gould en vele anderen overtuigend bewijs geleverd voor de stelling dat claims over de aangeboren inferioriteit van mensen (racisme, seksisme, antisemitisme) berusten op mismeasure door de belanghebbenden. ${ }^{16}$ De biologie als standaard voor het denken over sociale verschillen heeft daardoor aan gezag ingeboet, al is tevens sprake van een recente revival van neodarwinistische theorieën. ${ }^{17}$ Dat neemt niet weg dat ook in Nederland in de afgelopen tien jaar nog met enige regelmaat is gesproken over de geringere ambitie van vrouwen of over de rol die 'testosteron' speelt in de 'harde vakken', soms door mannen met veel wetenschappelijk gezag. ${ }^{18}$ Een frappant fragment uit de VPROdocumentaire Verlies van talent, over vrouwen in de wetenschap, is de uitspraak van een woordvoerder van de KNAW dat vrouwen die hoogleraar willen worden, niet ook nog eens de a mbitie moeten hebben om hun eigen kleren te naaien. ${ }^{19}$ 
lets anders is dat door het verklaringsmodel van de essentiële verschillen ook het moederschap nog steeds als een handicap voor vrouwen met ambitie wordt gezien, al worden hiervoor tegenwoordig meer sociale dan biologische argumenten aangevoerd. Dat hier sprake is van een cultureel vooroordeel, waarin het zorgen door werkende vaders als een verrijking wordt bejubeld terwijl het werken door zorgende moeders als zeer problematisch wordt afgeschilderd, heeft de Maastrichtse cultuurwetenschapper Lies Wesseling overtuigend laten zien. ${ }^{20}$

De tweede traditionele verklaring voor de geringe aantallen vrouwelijke hoogleraren is dat 'vrouwen in de pijplijn zitten'. Deze uitleg erkent dat er in het verleden juridische en culturele barrières waren, in de vorm van ge- en verboden die het vrouwen bemoeilijkten een wetenschappelijke carrière op te bouwen. Deze barrières waren echter niet intrinsiek aan het verschijnsel wetenschap, maar waren het gevolg van de maatschappelijke context waarin de wetenschappers hun werk deden. Maar die tijd is voorbij, vrouwen zijn inmiddels geëmancipeerd en met een beetje geduld zal de kloof over niet al te lange tijd vanzelf overbrugd zijn.

Ook dit argument is niet sterk genoeg, zoals alleen al blijkt uit het feit dat er geen sprake is van een geschiedenis van gestage vooruitgang gerelateerd aan toenemende studentenaantallen. Zo werden in het begin van de jaren negentig enkele studies gepubliceerd waaruit de desastreuze uitwerking van universitaire herstructureringsoperaties op de vrouwelijke leden van het wetenschappelijke personeel in de jaren zeventig en tachtig bleek. ${ }^{21}$ Was het percentage vrouwelijke hoogleraren in 1970 2,7, in 1988 was dat aandeel gekrompen tot 2,2\%, of in ronde getallen: het aantal vrouwelijke hoogleraren liep in deze periode terug van 65 in 1970 naar 50 in 1988, de vrouwelijke lectoren / hoofdmedewerkers / universitaire hoofddocenten van 312 naar 105. En dat tijdens de hoogtijdagen van de tweede feministische golf in Nederland, toen tevens enkele nieuwe leerstoelen op het gebied van vrouwenstudies werden ingesteld. Het pijplijnargument strookt evenmin met het feit dat ook in disciplines waar van oudsher al veel vrouwen in werkzaam waren, vrouwen in de top zijn ondervertegenwoordigd, en vaak relatief nog sterker dan in vakken waar vrouwen traditioneel in de minderheid waren. 
lets anders is dat Europea-wijd vrouwen weliswaar een minder grote kans hebben dan mannen om hun investering in de studie terug te verdienen in de vorm van leerstoelen, maar dat er niettemin grote nationale verschillen zijn die niet zondermeer te verklaren zijn uit meer en minder emancipatie. Vandaar dat tegenwoordig gesproken wordt van de 'lekkende pijplijn'. In het ETAN-rapport voor de Europese Commissie, waaraan ik het geluk had een bijdrage te mogen leveren, is daarvoor vanuit de Duitse federale beleidscontext de figuur van de scissors of het schaardiagram geïntroduceerd. ${ }^{22}$ Daaruit blijkt goed dat nog steeds iedere carrièrestap een hobbel is die groter blijkt voor vrouwen dan voor mannen.

The Scissors: Proportion of women and men in a typical academic career, students and academic staff, EU25, 1999-2003

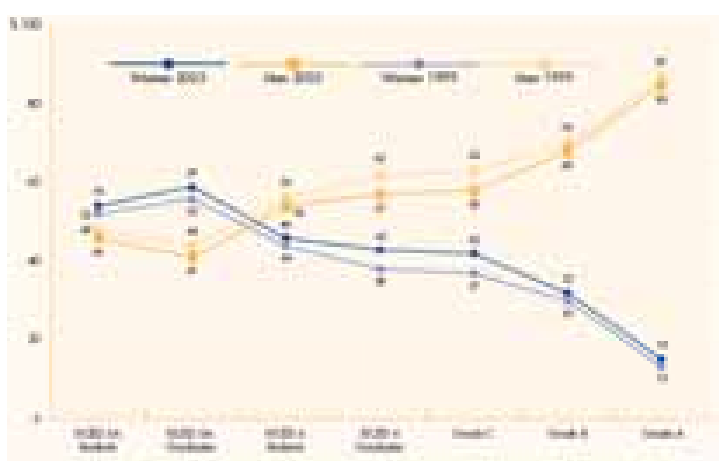

Source: European Commission, Women \& Science: Latest Statistics and Indicators - She Figures 2006, p. 55

Afgezien van deze statistische argumenten tegen een te lichtvaardig geloof in gestage of zelfs mechanische vooruitgang, kan gewezen worden op enkele spraakmakende 'gevallen' van op zijn zachtst uitgedrukt 'ongelijke behandeling', die tot nadenken zouden moeten stemmen. De eerste casus kwam in 1975 aan het licht. Het betrof Rosalind Franklin, de vrouw die erkenning voor de ontdekking van de structuur van het DNA-molecuul misliep. In een recente aflevering van de VPRO-serie Zomergasten liet de Vlaamse microbioloog en Alzheimeronderzoeker Christine van Broeckhoven een fragment uit een documentaire over Franklin zien. De beslissende foto die zij maakte van het Deoxyribo Nucleic Acid-molecuul werd door haar naaste collega in King's College in Londen, Maurice Wilkins, buiten haar weten aan Francis Crick en James Watson getoond, waarna de laatste twee prioriteit claimden voor hun 
ontdekking van de dubbele helix. De drie mannen kregen vervolgens in 1968 de Nobelprijs, tien jaar nadat Franklin was overleden, waarschijnlijk aan de gevolgen van haar radioactieve fotowerk. Haar aandeel in de geschiedenis van deze ontdekking werd al in 1975 uiteengezet door Anne Sayre, en zette wereldwijd de toon voor andere verhalen over 'what it is like to be a gifted woman in an especially male profession', zoals de ondertitel van het boek hierover luidde. ${ }^{23} \mathrm{lk}$ kom daar nog op terug.

Een tweede casus was het opzienbarende onderzoek naar het peer-reviewproces van de Zweedse Medische Onderzoeksraad door de onderzoekers Christine Wennerås en Agnes Wold in 1997.24 De uitkomst daarvan kreeg wereldfaam na publicatie onder de titel 'Nepotism and sexism in peer-review' in het gerenommeerde wetenschappelijke tijdschrift Nature. Op grond van hun eigen slechte ervaringen met de Zweedse Medische Onderzoeksraad vroegen zij zich af of vrouwelijke aanvragers wel 'fair' werden behandeld. Werd het onderzoek van vrouwen wel in gelijke mate en op dezelfde gronden gehonoreerd als dat van mannen? Het antwoord was onthutsend: alleen de productiefste vrouwelijke aanvragers werden even competent geacht als mannen; even competent, let wel, als de minst productieve mannelijke aanvragers. Hun op meervoudige regressie-analyse gebaseerde inzichten bevestigden het vermoeden dat vrouwen twee keer zo goed moesten zijn als mannen om door selecties te komen.

Voor wie in gestage vooruitgang gelooft, zijn deze kwesties niet het mogelijke topje van de ijsberg, maar atavistische uitzonderingen die de regel bevestigen: tijdelijke en plaatselijke aberraties, of gevallen van discriminatie, die niet systematisch zijn. ${ }^{25}$ Dat was ook de betekenis die een vertegenwoordiger van NWO desgevraagd aan de Zweedse casus gaf in de al eerder genoemde VPRO-documentaire Verlies van talent. ${ }^{26}$ Maar de vraag is hoeveel uitzonderingen een regel nog kan verdragen. Wanneer wordt het paradigma waarop de verklaringen berusten vervangen?

\section{Gender als nieuw paradigma}

Feministische wetenschappers zijn minder overtuigd van het feit dat de natuur of de vooruitgang in dezen beslissend is. Evenmin kunnen zij goed uit de voeten met de term 'discriminatie' vanwege het al te opzettelijke en persoongebonden karakter van wat onder 'discrimineren' wordt verstaan. In plaats van doelbewuste acties van 
onwelwillende mannen die onwennige vrouwen buiten de deur proberen te houden, hebben zij het over een proces waarin mannen én vrouwen verwikkeld zijn en dat leidt tot Glazen plafonds, Kleverige vloeren of Hoogtevrees. Zij laten zich daarbij onder andere inspireren door grote paradigmatische denkers als Virginia Woolf en Simone de Beauvoir. Woolf, bijvoorbeeld, liet de ik-persoon in A room of one's own uit 1929 al tot de verbazingwekkende conclusie komen dat het antwoord op de vraag waarom mannen en vrouwen zulke verschillende levens leidden niet te vinden was in de boeken, maar in de verbazingwekkende omstandigheid dat er over vrouwen zovéél boeken werden geschreven. ${ }^{27}$ Als De Vrouw al niet wezenlijk anders was dan De Man, dan werd zij het in en door die teksten wel gemaakt. Ditzelfde inzicht zou haar Franse collega Simone de Beauvoir twintig jaar later in die andere grote klassieker van de twintigste eeuw samenvatten in de zin: 'On ne naît pas femme, on le devient.'28 (Je komt niet ter wereld als vrouw, je wordt vrouw.) Daarmee werd - althans voor de goede verstaander - het afscheid van 'de biologie als lot' bezegeld.

De feministische wetenschappers die in de vorige eeuw de analyse van sekseverschillen op de universitaire onderzoeksagenda zetten, zetten zich in navolging van De Beauvoir aan een systematische ontleding van de bestaande productie van wetenschappelijke teksten over vrouwen en mannen en het sekseverschil. ${ }^{29}$ Daaruit bleek dat de wetenschap zelf een belangrijke rol had in het definiëren en bevestigen van het sekseverschil. Dat besef leidde in de jaren tachtig tot het analytische concept 'gender', ter aanduiding van twee onderscheiden maar gerelateerde fenomenen. ${ }^{30}$ In de eerste plaats kwam gender als sociale categorie te staan voor de manier waarop ideeën over sekse en sekseverschillen, mannen en vrouwen hun plaats wijzen in het sociale verkeer - in instituties en instellingen, en hun tevens vertellen wie zij zijn en hoe zij zich horen te gedragen. Hierin spelen niet alleen biologische, psychologische en andere wetenschappelijke theorieën een rol, maar ook huis-tuin-en-keukenopvattingen over mannen en vrouwen en juridische regelgeving op allerlei gebied. Een belangrijke winst van het concept 'gender' was dat het ook 'mannelijkheid' als een sociale categorie zichtbaar maakte. Ook mannen worden tot 'mannen', zo wees het onderzoek uit, al naar gelang de context en altijd in relatie tot vrouwen en vrouwelijkheid. En niet altijd alleen maar of in alle opzichten in het voordeel van mannen. Tenslotte maakte het door en door sociale karakter van gender ook de verknoping met andere 
'cruciale verschillen' zichtbaar. Niemand wordt alleen maar gedefinieerd door gender, maar ook altijd en altijd gelijktijdig door andere sociale categorieën als leeftijd, klasse, religie en etniciteit.

In de tweede plaats (maar onlosmakelijk met het vorige verbonden) bleek gender als symbolische categorie, in de vorm van impliciete of expliciete verwijzingen naar mannelijkheid en vrouwelijkheid, een rol te spelen in de vestiging of ondermijning van hiërarchische verhoudingen. Dit betekent dat op symbolisch niveau een permanente 'seksenstrijd' gaande is die niet direct (maar toch wel indirect) met 'real life' mannen en vrouwen te maken heeft. Een belangrijk vehikel voor gender als uitdrukking van macht en hiërarchie zijn binaire opposities als objectiviteit versus subjectiviteit, ratio versus gevoel, distantie versus betrokkenheid, harde of kwantitatieve methoden versus zachte of kwalitatieve methoden. De pool die de norm aangeeft cq hoger in aanzien staat is met mannelijkheid geassocieerd. Hieruit is te verklaren dat nogal wat vrouwen de twijfelachtige eer ten deel valt te worden geprezen als een 'kerel', al zijn de bewoordingen soms subtieler dan dat. Zo zag de bouwkundig ingenieur Ko Mulder, de latere 'Juffrouw van het (Amsterdamse) bos', in 1926 haar onder pseudoniem ingezonden ontwerp voor een brandweerkazerne met de eerste prijs bekroond om zijn 'stoer manlijke geest'.31

Wetenschapsgeschiedenis en gender als sociale categorie

In de laatste vijfentwintig jaar is door genderonderzoekers hard gewerkt aan het ontwikkelen van een verfijnder inzicht in de vraag waarom er nog steeds zo weinig vrouwelijke topwetenschappers zijn. De historici onder hen, zoals ikzelf, deden dat door na te gaan hoe gender werkt in de verschillende contexten van disciplines, universiteiten, onderzoeksinstituten en laboratoria. Een belangrijk eerste inzicht van dit onderzoek was dat er in de afgelopen honderd jaar eigenlijk helemaal niet 'zo weinig vrouwen' waren geweest. De meeste vrouwelijke wetenschappers waren echter door hun ondergeschikte positie in de organisatie onzichtbaar gebleven en daardoor vervolgens ook niet tot de annalen doorgedrongen.

Vooraanstaand systematisch werk in dezen werd geleverd door Margaret Rossiter in haar baanbrekende drieluik over 'Women Scientists in America' van 1870 tot nu. ${ }^{32}$ Op basis van minutieus bronnenonderzoek en een ingenieus gebruik van kwantitatieve gegevens liet zij zien dat 
de steeds verdergaande professionalisering en hiërarchiesering van de wetenschap en de ontwikkeling van Big Science strikt parallel liepen met en misschien wel gezien moeten worden als het antwoord op de steeds grotere aanspraken die vrouwen maakten op het recht om met hun steeds betere opleiding ook een wetenschappelijke carrière op te bouwen. Vrouwen mochten dus wel degelijk meedoen, maar wel op beperkte voorwaarden, als vrijwilligers, als uitzonderingen op de regel of als assistenten van. Zij liet het ontstaan zien van 'typisch vrouwenwerk in de wetenschap', bijvoorbeeld dat van de rekenkundigen in de astronomie, en wees op het belang van compenserende strategieën in de vorm van vrouwenbeurzen of vrouwenprijzen. Andere historici als Londa Schiebinger en Margaret Phillips gingen terug in de tijd en maakten aannemelijk dat vrouwen en de natuurwetenschappen niet altijd twee bijna uitsluitende grootheden waren geweest. ${ }^{33}$

Rossiter was ook degene die het Matilda-effect muntte, als variatie op het Matteüs-effect, het verschijnsel (naar een tekst uit het evangelie van Matteüs) dat wie al veel heeft nog veel meer zal krijgen dan hij had. 34 In de wetenschap betekent dit dat aan wie al beroemd is nog veel meer wordt toegeschreven dan diegene in werkelijkheid zelf heeft gedaan. Het Matilda-effect gaat over het tweede deel van deze tekst uit Matteüs, namelijk dat wie al niets heeft, ook nog zal worden ontnomen wat hij had. Dat was volgens Rossiter de gangbare situatie voor vrouwen in de wetenschap, die voor het overgrote deel hun aandeel in ontdekkingen en claims van prioriteit, door hun ondergeschikte positie, verloren aan hun bazen.

Mijn eigen analyse van de wetenschappelijke carrières van vrouwelijke universitaire docenten (hoogleraren, privaatdocenten en lectoren die tussen 1900 en 1950 benoemd werden door de kroon) in Nederland, liet eveneens zien dat voor vrouwen het bevorderingssysteem niet op dezelfde manier werkte als voor mannen. Daardoor zijn ook de namen en daden van vele in hun vak vooraanstaande Nederlandse onderzoekers als Marianne van Herwerden, Antonia Korvezee, Anita Steenhauer, Louise Kaiser en Jannetje Schuiringa nagenoeg onbekend gebleven. ${ }^{35}$

Gegeven de afhankelijke positie waarin vrouwen heel lang hun werk moesten doen, is een interessante invalshoek die van de 'creatieve koppels', veelal samenwerkende echtgenoten in de wetenschap gebleken. ${ }^{36}$ Daaruit blijkt dat het huwelijk behalve een nadeel ook heel 
vaak een voordeel was voor vrouwen, of zelfs de beste mogelijkheid voor vrouwen om überhaupt een onderzoeksplaats te bemachtigen en enige zichtbaarheid als wetenschapper te verwerven. Hetzelfde geldt trouwens voor heel veel dochters. Niettemin viel hen zelden de bij hun verdiensten passende waardering ten deel, zoals blijkt uit een aantal Nobelprijzen dat door mannen werd geïncasseerd voor onderzoek dat zij geheel samen met (hun) vrouwen hadden verricht.37 Juist de focus op vrouwen of op de samenwerking tussen mannen en vrouwen in de context van een specifieke laboratoriumcultuur en het wijdere verband van politiek en industrie, laat aspecten zien van het proces van wetenschap die verdwijnen in de traditionele focus op individuele genie en persoonsgebonden excellentie. ${ }^{38}$ Daarmee gaat het belang van dit soort onderzoek ook verder dan alleen het blootleggen van genderaspecten, en laat het uiteindelijk zien hoe wetenschappelijke waarheid sociaal is ingebed in hiërarchie en ongelijkheid in sociale verhoudingen en arbeidsrelaties. Door het principe van de 'winner takes all' is in veel gevallen de waarheid over wetenschap als teamsport de verliezer. 39

\section{Wetenschapsgeschiedenis en gender als symbolische categorie}

Ons begrip van hoe wetenschap werkt profiteerde eveneens van de uitvinding van gender als symbolische categorie. Al in het eind van de jaren zeventig wezen Carolyn Merchant en Brian Easlea op de grote verandering die de betekenis van 'natuur' onderging in relatie tot de moderne experimentele wetenschapper. ${ }^{40}$ Zo schreef Francis Bacon (de zogeheten vader van de proefondervindelijke wijsbegeerte) herhaaldelijk over de natuur als een vrouw die overgehaald of gedwongen moest worden zich in haar diepste innerlijk te laten kennen door een wetenschapper. ${ }^{41}$ Andere vroegmoderne wetenschappers kenmerkten de nieuwe wetenschappelijk methode als het ontraadselen, het ontsluieren, het op de pijnbank leggen of overweldigen van de natuur om haar haar mysteries te ontfutselen. Dit soort verwijzingen naar de wetenschappelijke methode is zo talrijk dat de wetenschapsfilosoof Donna Haraway deze metaforen heeft gerangschikt onder de welsprekende noemer van de epistemologische erotica. ${ }^{42}$ Deze historische interpretaties braken vooral in het eind van de jaren zeventig en begin jaren tachtig door toen ook de verwoestende kracht van de wetenschap als Father of the Unthinkable, namelijk de kernbom, onder vuur lag. ${ }^{43}$ Feministische theorie en wetenschapskritiek droegen er samen toe bij om mannelijkheid en agressiviteit verpakt als onpartijdige objectiviteit en wetenschap in één duidelijke ideologische lijn te zien. 
Parallel met en deels geïnspireerd door de denaturalisering van sekse, liep de culturalisering van wetenschap. Het inzicht dat wetenschap een sociaal, cultureel en politiek proces is, waarbij geen pertinent onderscheid kan worden gemaakt tussen sociale context en de inhoud van wetenschap, heeft in de laatste decennia een enorme impuls gegeven aan de wetenschapsgeschiedenis. Zo legden Simon Shaffer en Steven Shapin in hun klassieke werk Leviathan and the Air-pump een intrigerend verband tussen de politieke filosofie van Thomas Hobbes en het experimentele werk van Robert Boyle. ${ }^{44}$ Daaruit bleek dat de wetenschappelijke experimenten en de 'kennis' die daaruit voortkwam waren ingebed in een heel scala van literaire en sociale technologieën, die werden gedragen door een gemeenschap van beschaafde 'natuuronderzoekers' die in alle openheid en bescheidenheid (als 'modest witness') hun vondsten met elkaar deelden. Anders dan de contemporaine universiteitsgeleerden, die vertrouwden op de klassieken en zich uitleefden in scholastieke uiteenzettingen, hoopten de vertegenwoordigers van de proefondervindelijke wijsbegeerte in de empirische feiten een gemeenschappelijk houvast te vinden, buiten en boven de religieuze twisten en de verschillen die de sociale orde verdeelden. Dat Hobbes met zijn Leviathan tegen deze zienswijze opkwam, plaatste niet alleen de veranderingen in de wetenschap maar ook in de politieke filosofie in een geheel ander licht.

Bijzonder vruchtbaar voor een begrip van hoe wetenschap werkt is het concept van de 'wetenschappelijke persona' als de belichaamde drager van sociaal ingebedde wetenschappelijke waarheid gebleken. Vroegmoderne wetenschappers bijvoorbeeld waren overtuigd van de noodzaak de hartstochten te bedwingen om betrouwbare kennis te produceren. Voor sommigen, zoals Boyle en Newton, betekende dat een keuze voor het celibaat, maar het kon ook de naleving van bepaalde leefregels inhouden, het volgen van een dieet of het bijhouden van een dagboek. ${ }^{45}$ Hoewel deze oefeningen in zelfbeheersing op zich niet eenduidig mannelijk genoemd kunnen worden, werden zij dat wel op het moment dat geleerde vrouwen zich in het debat mengden. Op dat moment bleken de passies te worden gezien als 'vrouwelijk' en tegenover het mannelijke intellect te worden gesteld. ${ }^{46}$

De wetenschappelijke persona was en is niet eenduidig en veranderde bijvoorbeeld van de beschaafde onafhankelijke aristocraat die Boyle 
belichaamde, de 'sick scientist' die Darwin vertolkte, de 'disembodied scientist' die Stephen Hawkins incorporeert, tot de viriele vrijbuiter die de contemporaine wetenschapper en Nobelprijswinnaar Kary Mullis laat zien in zijn autobiografie. ${ }^{47}$ In die figuur vertolkt hij naast de rol van de moderne, fysiek krachtige onderzoeker, de klassieke rol van excentrieke, op het randje van gekte balancerende geniale geleerde. De meeste vertolkingen van de wetenschappelijke persona, waarop ook weer publieke beelden van wetenschap en wetenschappers zijn gebaseerd, zijn op de een of andere manier verknoopt met betekenissen van mannelijkheid, maar niet allemaal en niet ondubbelzinnig. $4^{8}$ Daarom is het voor vrouwen moeilijk om voor een 'betrouwbare getuige' (of excellente wetenschapper) door te gaan, maar niet helemaal onmogelijk. Dat heeft de cultuurwetenschapper Lies Wesseling onlangs laten zien in een prachtige analyse van het werk van de Amerikaanse pedagoge Judith Harris, die met haar theorieën over de invloed van leeftijdgenoten op de opvoeding vanuit de zijlijn doordrong tot de top van haar discipline. Zij deed dat door zich enerzijds 'als vrouw' onzichtbaar te maken en tevens gebruik te maken van oude repertoires als de geheel onafhankelijke en daardoor oprechte vertolker van de (nieuwe) waarheid. 49

\section{WAAROM WORDT DE WETENSCHAP NIET WIJZER?}

In de laatste decennia is dus op basis van historisch onderzoek heel veel kennis verkregen over de manier waarop gender een rol speelt in de wetenschap als een epistemologisch en sociaal proces. De vraag waarom het zo langzaam gaat met de doorstroom van vrouwen naar topposities in de wetenschap valt op basis hiervan dan ook al heel goed te beantwoorden, al blijven er nog steeds heel veel vragen, topics en thema's over die in het kader van de leerstoel 'Gender en wetenschap' te onderzoeken zijn. In plaats van u hier dat gehele onderzoeksprogramma te ontvouwen, heb ik ervoor gekozen $u$ een deelprobleem en een daarbij behorend deelprogramma voor te leggen, iets dat past bij mij als historicus, en ook past bij de context van deze oratie, het congres WISER. De vragen die ik hier nu wil beantwoorden zijn: Waarom dringt deze kennis niet in brede kringen van wetenschappers door? Waarom is verspreiding van deze kennis zo vreselijk moeilijk te bewerkstelligen in een domein dat geacht wordt rationeel te zijn en de waarheid hoog in het vaandel te dragen? Waarom wordt de wetenschap maar niet wijzer? 


\section{De last van de overlevering}

Het antwoord op de vraag waarom kennis over gender en wetenschap zo hardnekkig gebrekkig blijft, wil ik in de rest van deze oratie zoeken in de last van de overlevering: alle verschillende vormen waarin wetenschappers elkaar herdenken en portretteren in In memoriams en gedenkboeken, biografische lemma's en lofredes. In mijn proefschrift Het geslacht van de wetenschap constateerde ik al dat vrouwelijke wetenschappers vaker en sneller vergeten werden en worden dan hun mannelijke collega's. Ook bleek dat de manier waarop mannen en vrouwen herinnerd worden verschillend was, wat deels weer samenhing met de sekse van de 'herinneraar'.50

De term 'overlevering' past in de context van het hedendaagse debat over het belang van memory, het collectieve herinneren, de waarde van herdenken, het vieren van jubilea en het oprichten van monumenten (of 'lieux de mémoires') voor het creëren van gemeenschap. ${ }^{51}$ Dit debat heeft zijn wortels in de 'memory wave', die onder andere het gevolg was van een democratisering en fragmentering van de historische ervaring. ${ }^{52}$ ledere groep heeft de behoefte aan reflectie op de gemeenschappelijkheid en eigenheid, ofde groepsidentiteit, en het creërenvaneen gemeenschappelijk verleden is daarbij sinds de Verlichting een standaardprocedure. Vandaar ook dat nieuwe naties, maar ook emanciperende groepen enthousiaste voortbrengers zijn van historische verhalen. Enerzijds ontstond kritiek op 'gecanoniseerde herinneringsmomenten en monumenten', anderzijds werden herdenkingsplaatsen opgericht die recht moesten doen aan de ervaringen van groepen die in het verleden slachtoffers waren of dat nog waren. De aldus van hun vanzelfsprekendheid ontdane officiële herdenkingsplaatsen zetten historici ertoe vervolgens ook andere 'lieux de mémoires' als betekenisvol te beschouwen en tot onderwerp van studie te maken. Een van de belangrijkste opbrengsten van die ontwikkeling is een verruiming van de 'historische cultuur' of, zou je kunnen zeggen, een culturalisering en antropologisering van de historiografie. Niet meer alleen professionele historische verhalen, maar ook herdenkingspraktijken en feestelijke vieringen van het verleden blijken van belang voor ons collectieve geheugen en onze daardoor geschraagde identiteit.

Mijn Maastrichtse collega-historicus Jos Perry heeft in een gedenkwaardig boekje, verschenen ter gelegenheid van het tweede lustrum van onze faculteit, een heldere en ontnuchterende beschouwing gewijd aan dit debat, en vervolgens de rijkdom laten 
zien van diverse vormen en functies van het hedendaagse herdenken. 53 Anders dan vele andere deelnemers aan dit debat ziet hij geen tegenstelling tussen 'levende traditie' en de (dorre) geschiedschrijving, maar veeleer continuiteit en wederzijdse ontlening. Ik denk dat hij daarin groot gelijk heeft: hoe vaak wordt niet ter gelegenheid van een herdenking een proeve van geschiedschrijving afgeleverd, of wordt een historisch werk de basis voor herinneringsarbeid. Interessant is dat Perry de wetenschap of het wetenschappelijke bedrijf een paar keer noemt als voorbeeld voor andere bedrijfstakken om zich aan het herdenken over te geven, zonder zich af te vragen waarom de wetenschap zo hartstochtelijk herdenkt. Is het een erfenis van de klerikale traditie? Heeft het herdenken met de daaraan gepaard gaande rituelen - die de wetenschappelijke autoriteit ook letterlijk op straat zichtbaar maken - te maken met het creëren van een academische gemeenschap en de bevestiging van macht?

Hoe dat ook zij, de wetenschap heeft een rijke herinneringscultuur met jaarlijkse diesvieringen, vijfjaarlijkse lustra, jubilea van instituten en ontdekkingen, personen en boeken. ${ }^{4}$ De oudste gebouwen van de academie worden vaak gekoesterd en tot centrum gemaakt van officiële plechtigheden, en waar dat niet kan, zoals in Maastricht, waar de universiteit pas in 1975 werd opgericht, worden oude imposantegebouwen betrokken. De oudste universiteiten pronken met adembenemende portrettengalerijen van voorgangers die in het academische portret soms hun enige blijvende betekenis verwierven. En waar die illustere voorgangers ontbreken door de jeugd van de universiteit, prijken soms de schilderijen van stadsregenten, zoals in de rechtenfaculteit van de UM. Vaak gaan de feesten en jubilea gepaard met het uitbrengen van soms ontilbare herdenkingsgeschriften, die meestal historisch zijn, een heel enkele keer ook niet, zoals het fraaie lustrumboek-met-een-knipoog dat de fotograaf Margriet Smulders maakte bij gelegenheid van het vijfenzeventigjarig bestaan van de Radboud Universiteit te Nijmegen.

Een belangrijk genre binnen die herinneringscultuur in de wetenschap zijn biografische teksten: wetenschappelijke monografieën, In memoriams, herdenkingsartikelen, feestredes voor de jubilaris, populaire biografieën, autobiografieën en interviews in allerlei soorten en maten. Maar met die biografische teksten is iets aan de hand. De wetenschappelijke biografie is namelijk een uiterst merkwaardig en zelfs paradoxaal genre omdat in het dominante ethos van de westerse wetenschap de wetenschapper 
het onpersoonlijke doorgeefluik is van ware kennis, zodat er dus eigenlijk geen biografie over een wetenschapper mogelijk is. Volkomen in strijd hiermee bestaat er echter een onophoudelijke productie van biografische teksten over wetenschappers vanaf de Wetenschappelijke Revolutie tot heden, al zijn er in de soorten beschrijvingen tijd- en plaatsgebonden verschillen in stijl. En wat nog merkwaardiger is: er vindt nauwelijks enige reflectie plaats over die stroom aan biografische betekenissen. En dat terwijl de wetenschappelijke biografie volgens Söderqvist weleens de belangrijkste bron van metawetenschappelijke kennis over de wetenschap zou kunnen zijn, met wellicht ook de grootste impact op de vorming van publieke kennis over de wetenschap. ${ }^{55}$ Niettemin ontbreekt het dit genre vrijwel aan kritische beschouwing vanuit de professionele wetenschapsgeschiedenis en wetenschapsfilosofie. ${ }^{56} \mathrm{Wat}$ is de culturele impact van die lawine aan biografische teksten in de wetenschappen? Hoeveel wetenschappers hebben zich daardoor laten rekruteren of afschrikken? Wat is de 'received wisdom' die door de wetenschappelijke biografie wordt doorgegeven, en hoe belangrijk is die voor het dagelijkse reilen en zeilen van het wetenschappelijke bedrijf?

Voor vrouwelijke wetenschappers zijn deze vragen uiterst relevant. Want biografieën zijn op zich al geen onproblematische genre voor vrouwen, zoals ik elders heb betoogd, vanwege de nadruk op 'historische grootheid' en 'historisch belang' die verbonden zijn met publieke handelingen en functies in de openbare sfeer. ${ }^{57}$ De meeste vrouwen bereiken niet die mate van zichtbaarheid, en als zij dat wel doen, dan is hun vrouwelijkheid steevast een zo overweldigend gegeven dat vrijwel alle teksten over vrouwen erdoor gestempeld worden. Voor biografieën van wetenschappers geldt dat om bovengenoemde redenen misschien nog wel des te meer, zodat hier de last begint van de overlevering.

MaaikeMeijerheeft in haarinspirerendeboekover representatietheorie In tekst gevat in de context van een bespreking over 'intertekstualiteit', of tekstuele ontlening, het concept 'cultuurtekst' geïntroduceerd. Zij doelt daarmee op 'het conglomeraat van geaccepteerde, steeds weer terugkerende motieven en wijzen van representatie rond een bepaald thema [...], dat zich steeds weer organiseert in nieuwe culturele teksten, ongeacht of deze literair, journalistiek, wetenschappelijk of van andere herkomst zijn'.58 Het lijkt mij dat we de biografische overlevering in de wetenschap als een cultuurtekst kunnen zien, die nauw is verknoopt met de uitdoktering van de diverse repertoires 
die voor de wetenschappelijke persona voorhanden zijn, en die vaak draaien om vormen van mannelijkheid. Die beelden van wetenschap en de wetenschapper zijn zo hecht verankerd in ons cultureel systeem dat de bonte veelkleurigheid van de werkelijkheid in biografische herinneringsteksten steeds wordt teruggebracht tot een beperkt aantal stereotiepe verschijningen van de 'mannen van wetenschap'. Dat verklaart waarom vrouwelijke wetenschappers ondanks dat zij al lang en in niet geringe mate wetenschappelijk werkzaam zijn, in de wetenschappelijke overlevering welhaast niet eens in beeld komen, en als zij zichtbaar worden, hun sekse voortdurend in het geding is. En het is nog sterker. De cultuurtekst van de wetenschappelijke biografie is zo dwingend dat de herinnering aan vrouwelijke wetenschappers hun nog minder ruimte geeft dan zij in werkelijkheid hebben gehad. Ik wil hier twee voorbeelden van geven.

\section{Marie Curie}

Het eerste voorbeeld van de manier waarop de overlevering de historische werkelijkheid 'overschrijft', is de herinneringsarbeid met betrekking tot Marie Curie.59 Je zou denken dat Marie Curies wetenschappelijke reputatie onkreukbaar is. Niet alleen ontving zij twee Nobelprijzen, waarvan een lang nadat haar echtgenoot Pierre gestorven was, maar zij zette ook in haar eentje nog enkele decennia lang als hoogleraar en directrice van het laboratorium dat aan Pierres leerstoel verbonden was, het werk voort waaraan zij samen met haar man begonnen was. Historisch onderzoek heeft inmiddels aangetoond dat Marie en Pierre beiden wetenschappelijk profiteerden van het huwelijk dat zij sloten. ${ }^{60}$ Door zich te verbinden met een wetenschapper van enige naam en faam kon Marie Curie niet alleen ontsnappen aan een carrière als lerares aan een meisjesschool in haar geboorteland Polen; zij kreeg via Pierre ook toegang tot een laboratorium, en tot de gemeenschap van wetenschappers. Pierre Curie daarentegen kreeg van Marie de nodige aansporing om eindelijk, vlak voor hun huwelijk, zijn promotie af te ronden, en een gerichtere focus op de wetenschappelijke arbeid en bijbehorende sociale verplichtingen te ontwikkelen. Hij was langzaam en bedachtzaam in zijn gedachtevorming en verloor dan ook prioriteit voor een aantal ideeën doordat hij eerst helemaal zeker van zijn zaak wilde zijn. Marie Curie was juist veel wilder in het formuleren van hypotheses en sneller in het bedenken van nieuwe experimenten en het doen van mededelingen daarover. Dat zij ook echt erkenning kreeg voor haar werk - al was er een verschil in de wijze waarop zij 
beiden werden beloond en is het haar bijvoorbeeld nooit gelukt lid te worden van de Académie - maar dat zij erkenning kreeg, is vervolgens het resultaat van een consequent volgehouden publicatiestrategie en Pierres onderhandse mededeling aan een lid van het Nobelprijscomité dat hij niet bereid was de Nobelprijs te aanvaarden als die niet ook aan zijn vrouw zou worden toegekend.

Desalniettemin is de herinnering aan Marie Curie in de populaire en wetenschappelijke literatuur niet onproblematisch. In de eerste plaats is ondanks haar beroemdheid en de overweldigende hoeveelheid publicaties over haar persoon, nog weinig echt goed onderzoek gedaan naar haar werk. In veel populaire boeken, maar ook in wetenschappelijke biografieën,verschijntzij bovendien als de'werkezel'ofdehardzwoegende scheikundige die het handwerk deed, naast Pierre, de natuurkundige, die het hoofdwerk verrichtte. Marie was degene die volgens de populaire overlevering hardnekkig volhield, 'ijverig als een mier', terwijl Pierre de briljante ideeën had. ${ }^{61}$
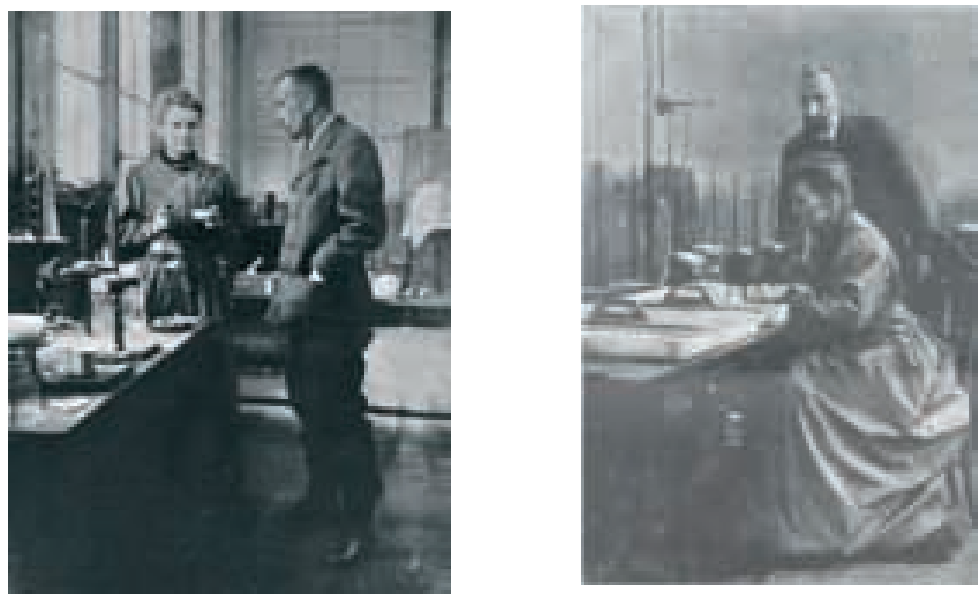

Marie en Pierre Curie in hun laberatorium omstreek 1900 

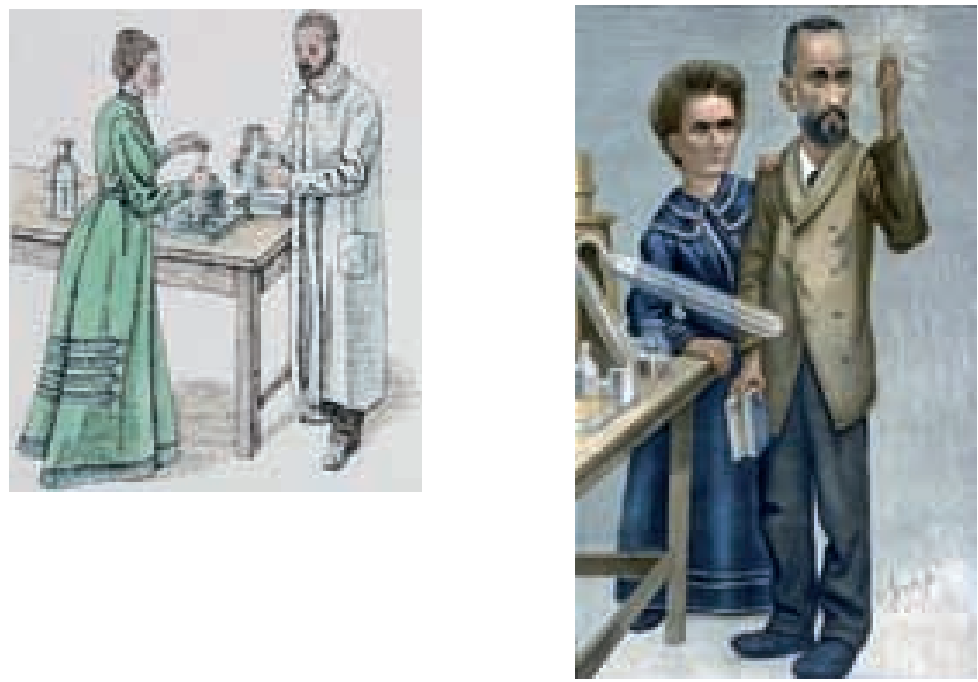

De originele foto's die van hen beiden in hun laboratorium bestaan, zouden deze zienswijze kunnen bevestigen, al zou je net zo goed kunnen zeggen dathijwat passief(hand in dezak) toekijkt,terwijlzijdewerksituatie actief beheerst en domineert. ${ }^{62}$ In de tekeningen - de overlevering die verder af staat van de (natuurlijk ook altijd gemanipuleerde) historische werkelijkheid op de foto - is de dubbelzinnigheid al veel minder aanwezig. Op de eerste tekening draagt Pierre een witte jas die hem herkenbaar tot de expert van hen beiden maakt, op de tweede is hij de actief leidende persoon en kijkt Marie over zijn schouder mee naar wat zijn ontdekking moet verbeelden. ${ }^{6}$ In al deze verschillen in waardering en toeschrijvingen van wie wat deed is voortdurend het Matilda-effect te zien. Dat is in haar geval dus niet zozeer tijdens haar leven met Pierre werkzaam, als wel in de herinneringsarbeid die pas na haar dood volop op gang komt. Interessant is ook de vraag naar welke periode van haar leven in de overlevering de meeste aandacht uitgaat. Het lijkt me niet toevallig dat juist door feministische onderzoekers haar rol als onderzoeksleider van een laboratorium waar altijd relatief veel vrouwen uit binnen- en buitenland werkzaam waren is onderzocht. ${ }^{64}$

\section{Rosalind Franklin}

Het tweede voorbeeld gaat over Rosalind Franklin, of eigenlijk niet zozeer over haar, als wel over de wijze waarop zij werd vereeuwigd in de grote bestseller over een van de belangrijkste ontdekkingen van de 
vorige eeuw: James Watsons The double helix. ${ }^{65}$ Inmiddels is het vrijwel algemeen bekend dat Franklins naam ten onrechte niet is verbonden aan het ontdekkingsproces van de structuur van DNA, gegeven het feit dat de foto die zij van het molecuul maakte doorslaggevend was. ${ }^{66}$ Minder bekend is echter dat de directe aanleiding voor Anne Sayre om deze unfaire geschiedenis te onderzoeken, de manier was waarop zij werd geportretteerd door Watson in zijn persoonlijke verhaal uit 1968. Een van de vele boekbeschrijvingen die van The double helix op internet te vinden is, maakt duidelijk wat de aantrekkingskracht is van deze klassieker, die niet lang geleden van de moleculair bioloog Wiel Hoekstra het predikaat 'schelmenroman' kreeg. ${ }^{67}$ Niet alleen belooft het een ontwapenend eerlijk en onopgesmukt verslag uit de keuken van een van de grootste ontdekkingen van deze eeuw, het boek levert ook een verbluffend zicht op de wetenschappelijke methode. Bovenal zit het vol met het soort wetenschappelijke anekdotes die steeds opnieuw, overal, in alle wandelgangen van universiteiten en laboratoria worden opgedist. 'It's the stuff of legends.' 68

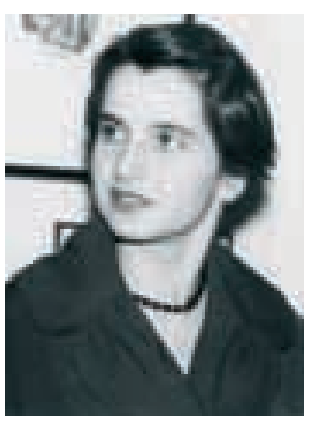

Verbluffend is The double helix echter vooral omdat de tekst laat zien hoezeer 'vrouwelijkheid' een rol speelde in de waarneming van de wetenschapper Rosalind Franklin door Watson en zijn collega's in Londen en Cambridge. Om te beginnen wordt zij in de hele tekst slechts een keer bij haar werkelijke naam genoemd. Dat is in de zin: 'Moreover, it was increasingly difficult to take Maurice's mind off his assistant, Rosalind Franklin,' waarmee zij wordt geïntroduceerd in het verhaal. ${ }^{69}$ Maurice wordt Maurice Wilkins bedoeld, die net als Franklin aan DNA werkte in een laboratorium in Londen, Watson en Crick zaten in Cambridge. Watson haast zich te verklaren dat er geen verliefdheid in het spel was, maar 'Rosy' weigerde zich als de ondergeschikte assistente van Maurice Wilkins te gedragen die zij volgens Watson was. In de 
rest van het verhaal verschijnt zij consequent als 'Rosy', 'as we called her from a distance', zoals hij schrijft, 'achter haar rug', bedoelt hij eigenlijk. Niemand die haar van nabij kende noemde haar zo. Door het boek heen verschijnt zij als een humeurig, kort aangebonden, rigide en on persoonlijk iemand. Een van zijn observaties van haar, bij een lezing die ze houdt over haar bevindingen, luidt: 'Er was geen spoortje van warmte of frivoliteit in haar woorden. En toch kon ik haar niet als helemaal oninteressant beschouwen. Zelfs vroeg ik mij op een gegeven moment af hoe ze eruit zou zien als ze haar bril zou afzetten en iets nieuws deed met haar haar.'70 Het laat zien dat zijn gevoelens ten opzichte van deze vrouw complex waren, om het mild uit te drukken.

VoorWatson, zo schrijft hij in The double helix, was op het oog zichtbaar dat zij niet gemakkelijk zou buigen. 'By choice she did not emphasize her feminine qualitities.' ${ }^{71}$ Post hoc is hier overduidelijk propter hoc, waarna hij uitweidt over het feit dat zij nooit lippenstift ophad en kleren droeg die zo uit de garderobe van een onvolwassen Engelse blauwkous konden zijn weggewandeld. Zijn oordeel was dan ook: 'Clearly Rosy had to go, or be put in her place.' Watson eindigt dit hoofdstuk met de woorden die in sommige kringen veel weerklank kregen: 'The real problem then, was Rosy. The thought could not be avoided that the best home for a feminist was in another lab.'72

Ik citeer hier niet zo uitgebreid alleen om u te shockeren, al is de tekst behalve ontluisterend ook nog eens misleidend. Franklin was namelijk helemaal niet Wilkins' assistent, maar zij beheerste een techniek waarvan zij en heel langzaamaan ook Watson en Crick begrepen dat die de doorslag zou geven bij de bepaling van de structuur van DNA. Ook was zij volgens Anne Sayre gezegend met een fantastisch gezichtsvermogen.73 Waar ik nu de nadruk op wil vestigen, is dat dit weliswaar vijttig jaar geleden is gebeurd, maar dat de tekst en het daarin vervatte plot over heroïsche jonge mannen of 'boys' en een onaantrekkelijke blauwkous nog steeds zijn werk doet en wordt herhaald. Hoewel inmiddels veel is gedaan om Franklin als medeontdekker van de dubbele helix te rehabiliteren, circuleert het boek nog steeds en inspireert het een publiek, dat misschien wetenschappelijk is gevormd, maar dat vaak niet getraind is in het herkennen van stereotypen, autobiografische heldenplots of standaardrepertoires voor de vestiging van wetenschappelijke autoriteit. Watson heeft duidelijk geput uit een beschikbaar repertoire van beelden en verhalen over vrouwelijke wetenschappers. Daarin komen heel veel 
'juffrouwen' voor en onelegant geklede vrouwen met brillen. Ook is bijna standaard sprake van uiteenzettingen over mannelijkheid en vrouwelijkheid, vaak ook in de vorm van anekdotes. Zo is bekend dat Johanna Westerdijk ooit door een collega werd begroet als 'Hallo kerel', en werd de begaafde Duitse wiskundige Emmy Noether zogenaamd 'liefkozend' betiteld als 'der Noether', waar zowel een verwijzing naar mannelijkheid als naar 'onzijdigheid' of 'de derde sekse' in zit.74 Maar Watson heeft ook geput uit heldenverhalen over ongebonden, arrogante, enigszins excentrieke maar ook weer niet al te afwijkende 'mannen der wetenschap', inderdaad, uit al die verhalen die 'are told and retold' binnen de muren van universiteit en laboratorium. ${ }^{75}$

Franklin heeft inmiddels al vele bewijzen van erkenning gekregen, die er soms zelfs toe leidden dat zij volgens haar biograaf Brenda Maddox 'began to be damned with praise'. Niettemin is de cultuurtekst over vrouwelijke wetenschappers in de herinneringscultuur van de wetenschap zo sterk dat zij nog steeds niet per definitie voorkomt in teksten over de ontdekking van de dubbele helix, en dat zelfs in het geval van de al gerehabiliteerde Franklin nieuwe stereotiepen hun marginaliserende werk doen. Zo werd er in 1989 een film over Franklin gemaakt waarin zij volgens Maddox verschijnt als een onwereldse 'droopy drudge' of mismoedige werkezel die urenlang over haar berekeningen gebogen zat zonder dat er een klacht over haar lippen kwam. Het strookt met de gedachte dat zij weliswaar al heel ver was in de ontraadseling van het probleem van de dubbele helix, maar dat haar het belang van haar ontdekkingen vooralsnog ontging. IJver verloor het met andere woorden van echte scherpzinnigheid. Niettemin is het een heel ander beeld dan mensen uit haar omgeving zich herinneren, namelijk dat van een bevlogen wetenschapper, die inderdaad urenlang, maar wel met passie en vol enthousiasme doelgericht aan het rekenen kon zijn. Ook wordt de opvatting dat zij een 'moeilijk' persoon was, en gehard door de strijd die zij met haar ouders moest leveren om het zover te brengen, steeds herhaald, zonder dat het enige grond heeft. ${ }^{76}$

Tegen deze onophoudelijke stroom van biografische beelden over vrouwelijke wetenschappers is vooralsnog bijna niet op te roeien. Toch zijn er - afgezien van de feministische productie van herinnering, en de fantasierijken genealogie van Westerdijk - veel voorbeelden van vooral vrouwelijke wetenschappers, en lang niet altijd feministen, die korter en langer geleden zelf protest hebben aangetekend tegen een 
herinneringscultuur in de wetenschap die hen kleineert of wegschrijft en die vervolgens zelf geschiedenis van vrouwelijke wetenschappers hebben geschreven. Een mooi voorbeeld is de bijdrage van Cornelia de Lange, de eerste gewoon hoogleraar Kindergeneeskunde in Nederland, in een rede bij het honderdjarige bestaan van de Koninklijke Nederlandsche Maatschappij der Geneeskunde in 1949. Tijdens die rede brengt ze eerst door middel van een citaat in herinnering wat de voorzitter vijfentwintig jaar geleden over de intrede van vrouwelijke artsen had gezegd. Nog tijdens het citaat, waarin van de vrouwelijke studenten werd gezegd dat zij 'al zijn zij wetenschappelijk zo goed als nooit uitblinkend, zij toch gemiddeld wat verstand, maar vooral wat ijver, volharding en plichts besef aangaat' niet voor mannen onderdeden, werpt De Lange tussen haakjes tegen: 'Och, die ijver waarover ons vrouwen steeds een verwijt wordt gemaakt!' En zij vervolgt het betoog met: 'Er is veel vriendelijks en waarderends in dit oordeel van de feestredenaar over vrouwelijke artsen, maar iets neerbuigends is er ook in.' Haar bijdrage zelf is vervolgens te zien als een poging om het overgeleverde beeld recht te zetten en de herinnering aan vrouwen als Aletta Jacobs, Catharine van Tussenbroek, Marie du Saar en Marianne van Herwerden als vrouwelijke medici en vele anderen op te halen. ${ }^{77}$

Een ander voorbeeld is de tentoonstelling Blauwkous? Vrouwenstudie aan de Nederlandse universiteiten en hogescholen die in 1959 werd ingericht in het Universiteitsmuseum van de Universiteit Utrecht, en die in de levens van heel veel vrouwelijke wetenschappers sporen heeft nagelaten..$^{8} \mathrm{Ik}$ kan me niet aan de indruk onttrekken dat het niet toevallig is dat juist iemand als de van oorsprong natuurkundige J.G. van Cittert-Eymers een dergelijke tentoonstelling organiseerde. Truus Eymers was een van de vrouwen die in de jaren twintig en dertig werkzaam waren op het befaamde laboratorium van Leonard Ornstein in Utrecht.79 Zij heeft dan ook van dichtbij meegemaakt hoe eerst Lily Bleeker na haar promotie haar ontslag nam, waarschijnlijk omdat zij voor de keuze stond met haar geliefde te huwen en ontslag te krijgen of met haar geliefde samen te gaan wonen zonder te huwen en dan haar ontslag te moeten nemen; en hoe niet lang daarna Miep Minnaert-Coelingh bij een andere hoogleraar dan Ornstein moest promoveren omdat Ornstein een gehuwde en zwangere promovenda niet duldde (ook niet als die de vrouw was van zijn collega Marcel Minnaert). De eerste, Bleeker, maakte buiten de universiteit vervolgens een prachtige carrière als ondernemende producent van optische instrumenten, waaronder in 
samenwerking met Frits Zernike de fasecontrastmicroscoop, waarvoor hij in 1953 zelfs een Nobelprijs zou krijgen. Het lot van Minnaert-Coelingh was minder fortuinlijk. Zij was een tijdlang zwaar depressief, misschien ook wel omdat zij en haar echtgenoot aanvankelijk hun idealen van 'samenwerkende echtgenoten' met zoveel verve hadden uitgedragen en er uiteindelijk van een wetenschappelijke carrière niets terechtkwam. ${ }^{80}$ Van Cittert-Eymers zelf had in de jaren dertig een centrale rol in het laboratorium. Zij voelde zich natuurkundige 'tot in haar vingertoppen', en heeft zich diep gekrenkt gevoeld toen zij bij haar huwelijk werd ontslagen. Is het toevallig dat nu juist zij - toen zij als directeur van het Universiteitsmuseum de kans had - een tentoonstelling over vrouwelijke wetenschappers inrichtte? En ook nog een over Anna Maria van Schurman?

Ook kan ik tenslotte nogmaals wijzen op Christine van Broeckhoven. Niet alleen tijdens de Zomergastenavond, ook in haar vorig jaar verschenen en al vele malen herdrukte autobiografie betuigt zij eer aan Rosalind Franklin, Marie en Eva Curie en de Nobelprijswinnares Rita LeviMontalcini.De manierwaropzijzichzelfen haarcollega-wetenschappers neerzet, getuigt bovendien van een krachtig tegengeluid: 'Vrouwen die tot de top van de wetenschap willen doorstoten moeten, naast de professionele uitdagingen, ook nog de energievretende strijd tegen vooroordelen over hun sekse aangaan.' ${ }^{81}$ Ik denk trouwens dat zij past in een trend waarin vrouwelijke wetenschappers hun ervaringen langzamerhand zijn gaan verwoorden in de vorm van verhalen die hun vanuit de feministische wetenschap zijn aangereikt. ${ }^{82}$

Ik ben ervan overtuigd dat wie echt werk wil maken van het aanboren van vrouwelijk talent op zijn minst aandacht moet besteden aan verkalkte beelden van wetenschap, als een typisch mannelijke aangelegenheid waarin mannen onveranderlijk een hoofdrol vervullen terwijl vrouwen alleen bij uitzondering of in een bijrol op het toneel verschijnen. Die beelden belemmeren het zicht op een werkelijkheid waarin allang heel veel aan het veranderen is. Het is geen fabeltje dat de kwaliteiten van vrouwelijke wetenschappers in heden én verleden nog steeds niet goed kunnen worden waargenomen omdat berichtgevers eerst en vooral getroffen worden door hun vrouwelijkheid (of juist onvrouwelijkheid). Het is geen toeval dat Marita Mathijsen in een recente $N R C$-column over de vraag waarom er in het afgelopen jaar maar liefst zes mannelijke (en niet één vrouwelijke) hoogleraren Nederlandse 
letterkunde zijn benoemd haar ongekroonde voorgangsters op een ronduit stereotiepe manier neerzet. ${ }^{83}$ (Al zou je ook kunnen zeggen dat zij beter zou moeten weten.) Zo beschrijft zij Elizabeth Kronenberg, die in 1951 een eredoctoraat ontving van de UvA, als 'een pittige tante, waarvoor mannen sidderden', terwijl zij de andere vrouwen onder de weinig heroïsche noemer van 'editeur' brengt: 'vlijtig, onvermoeibaar, vasthoudend en onderdanig'. Evenmin lijkt het mij toeval dat in het vijfentwintigjarig-jubileumnummer van de NRC-bijlage 'Wetenschap en Onderwijs', 24 februari 2007, aan de auteur van het meest geciteerde Nederlandse artikel uit 1982, Annelies de Klein, geen apart portret is gewijd, zoals bij drie van de andere wetenschappers wel werd gedaan. Blijkens een klein berichtje op de voorpagina van de krant die dag, werd vooral noemenswaardig geacht dat zij als de enige vrouw op de lijst van acht best geciteerde auteurs, tevens de enige was die geen hoogleraar werd. Maar een nadere beschouwing van haar werk, en een blik op De Klein als wetenschapper, wordt haar en ons niet gegund. Opvallend is bovendien dat bij de mannen die destijds als promovendi hun publicaties schreven niet en bij haar wel expliciet wordt vermeld tot wiens onderzoeksgroep zij behoorde. Is het te ver gezocht om in dit proces van on/zichtbaar-making een parallel te zien in benoemingsprocedures, waar het ook gaat om het waarnemen van de kwaliteiten van kandidaten?

Herinneringscultuur en biografische overlevering spelen mijns inziens een sleutelrol in de kwestie van de 'ondervertegenwoordiging van vrouwen in de wetenschap'. Juist omdat de wetenschap zich geen rekenschap geeft van haar onophoudelijke productie van biografische herinnering of de constante staat van herdenking waarin zij verkeert, is er een voortdurende stroom van betekenissen die vrouwelijke wetenschappers tot een wandelende contradictie maken. ${ }^{84}$ Denk alleen maar aan de alomtegenwoordigheid van alle geleerde voorgangers in de dagelijkse werkomgeving. Hoewel er dus doorlopend wordt herdacht, gebeurt dat onkritisch en ongereflecteerd, omdat dat indruist tegen een wetenschappelijk ethos dat in het teken staat van constante vernieuwing door onpersoonlijke denkers.

Beelden uit het verleden doen er toe, óók of eigenlijk júist in het heden. De 'memory wave' heeft ons de bemoeienis van vrouwen laten zien met het straatnamenbeleid in gemeenten of met het aanbrengen van plaquettes als dat van - heel binnenkort - de eerste vrouw in 
de Maastrichtse gemeenteraad Anna Wijnandts-Louis. Maar je kunt ook denken aan de oprichting van in onwillekeurige volgorde het slavernijmonument in Amsterdam, het grote holocaustmonument in Berlijn en de Vietnam Memorial in Washington, alsook het doorzettingsvermogen dat dit soort projecten vereisen en de politieke spanningen die erdoor worden opgeroepen. Ook het herdenken zelf kan een voortdurende bron van conflict blijven, zoals Annet Mooij heeft laten zien aan de hand van de herdenkingsgeschiedenis van de Februaristaking. ${ }^{85}$

Hoewel een monument een goede manier kan zijn om de aandacht bij de les te brengen en te houden, pleit ik niet voor een tastbaar monument voor de miskende vrouwelijke geleerde. Wel wil ik mij voor wat de historische invulling van mijn leerstoel betreft inzetten voor een drietal zaken:

1) Een kritische en systematische reflectie op de herinneringscultuur in de wetenschap, biografisch en niet biografisch, op de werkvloer en in de geschiedschrijving over wetenschap en wetenschappers. Wat is de rol van geschiedschrijving en herinnering voor het functioneren van wetenschap op de werkvloer? Graag wil ik de universitaire gemeenschap en de ruimere wereld van wetenschap het besef bijbrengen dat het niet zozeer mannen zijn die geschiedenis maken, maar dat juist de geschiedenis mannen maakt.

2) Onderzoek naar de geschiedenis van gender en wetenschap in de breedste zin, en aansluitend bij de nieuwste ontwikkelingen op het gebied van 'mainstream' wetenschapgeschiedenis, in de hoop dat ook omgekeerd die aansluiting wordt gezocht. Ik ben het geheel met Haraway eens wanneer ze zegt dat de 'failure to engage has not been symmetrical'. Het wordt namelijk ook tijd dat wetenschapshistorici beseffen dat het niet alleen mannen en vrouwen zijn die wetenschap produceren, maar dat ook het omgekeerde waar is, dat de wetenschap mannen en vrouwen produceert.

3) Systematisch en gefundeerd maar toegankelijk gepresenteerd onderzoek naar vrouwelijke wetenschappers in heden en verleden, liefst in samenwerking met erfgoedinstellingen als het IIAV en de diverse universiteitsmusea. Dat moet aan het licht brengen wie in Nederland (en in andere Europese landen) ons als hoogleraren zijn voorgegaan, maar ook aan wie dat niet vergund was. Wanneer de eerste vrouwen waar gingen studeren en wanneer en waar 
de eerste vrouwelijke universitaire assistenten werden benoemd. Hier zou een dynamisch, voor iedereen toegankelijk, virtueel monument van kunnen worden gemaakt, naar voorbeeld van de Finse tentoonstelling Women of Learning (Tiedenaiset), die in 2000 online ging, gelijktijdig met een 'real life' tentoonstelling. ${ }^{86}$ De kern daarvan zal een combinatie moeten zijn van biografisch woordenboek en encyclopedie, en gebaseerd op degelijk bronnenonderzoek, maar in de schil zal ruimte moeten zijn voor kinderboeken, autobiografische herinneringsarbeid, oral history en visuele herinneringspraktijken als documentaires en speelfilms, spel en debat.

En als er dan af en toe tijd over is, moeten we zelf herdenken, ons onze eigen daden in herinnering brengen en die van hen die ons zijn voorgegaan. Het liefst in de best mogelijke traditie die er op dit gebied is gevestigd door de eerste vrouwelijke hoogleraar in Nederland, Johanna Westerdijk: met humor, een grote dosis relativering en op de maat van de muziek! Na mijn dankwoord zal daar alvast een begin mee worden gemaakt met het zingen van de 'March of the University Women' door het Maastrichtse koor 'Femmes Vocales' onder leiding van Cécile Schouten.

Meneer de rector, dames en heren

In deze openbare les heb ik geprobeerd $u$ een inkijkje te geven in de manier waarop ik inhoud wil geven aan het leerstoelgebied Gender en wetenschap: met één been in het interdisciplinaire veld van gender en diversiteitsonderzoek, met een ander been in het archief, met één vinger aan de pols van het beleid, een andere vinger aan de pols van de wetenschapsgeschiedenis, en met de blik altijd op de toekomst. Net als in de afgelopen jaren wil ik mij in mijn werk niet beperken tot alleen het geschreven en gesproken woord, maar ook denken aan documentaires en publicaties voor een groter publiek. Behalve het forum van de internationale wetenschap wil ik ook het lokale, nationale en Europese onderzoeksbeleid opzoeken.

In het verleden zijn onze interventies op het gebied van het genderbeleid van deze universiteit ons niet altijd in dank afgenomen. Ik herinner mij dat er even sprake is geweest van enige commotie toen wij een kleurig spandoek met sprekende cijfers over het schrijnend lage aantal vrouwelijke hoogleraren aan de UM van de gevel lieten wapperen. Wij voelden ons geprovoceerd door het spandoek recht tegenover 
onze burelen met de uitdagende leuze: 'De UM alweer de beste!' Dat het College van Bestuur mij nu heeft benoemd in het kader van het beleid om meer vrouwelijke hoogleraren aan de UM aan te stellen, is het beste bewijs dat heftige verschillen van mening kunnen leiden tot veranderingen ten goede. Ik bedank de hier aanwezige leden, Gerard Mols en Jo Ritzen, voor het in mij gestelde vertrouwen. In een adem met hen wil ik Rein de Wilde bedanken, de decaan van onze faculteit, die met zo veel vaart het Collegebeleid om meer vrouwelijke hoogleraren te benoemen in daden heeft omgezet. Mogen nog vele anderen mij volgen, in de gehele universiteit!

\section{Waarde studenten}

De bijzondere positie van het Centrum heeft ons diverse keren voor de vraag gesteld of wij niet al het onderwijs zouden moeten afstoten en ons uitsluitend zouden richten op het doen van onderzoek. Als een door de nood gedwongen scherp calculerende eenheid lijkt het niet verstandig om financieel toe te moeten leggen op het draaien van minores. Maar de waarheid is: we kunnen helemaal niet zonder jullie; en we willen ook niet zonder jullie: jullie kritische vragen, jullie nieuwsgierigheid en leergierigheid en het vermogen om ons steeds weer spiegels voor te houden. Ik dank jullie daarvoor.

\section{Waarde collega's}

Ook jullie verdienen mijn grote dankbaarheid. Allereerst natuurlijk Maaike, professor Meijer, die nu alweer negen jaar geleden aan de oproep gehoor gaf om in het zuiden school te maken met haar sprankelende ideeën over populaire cultuur en vele andere zaken. Het tweede lustrum komt er al weer aan, dat moeten we zeker uitbundig vieren! Gelukkig zijn we heel verschillend en hebben we geen van beiden een talent voor ondergeschiktheid. We gaan dan ook allebei heel eigenwijs onze eigen gang, maar wel altijd in vriendschap en zo met elkaar in de pas dat we erin zijn geslaagd voor het Centrum onlangs een permanente verblijfsvergunning te bemachtigen. Annelies van der Horst, van jou heb ik geleerd de universitaire organisatie niet zozeer als een tegenstander te zien als wel als een medespeler. Samen hebben we eerst de universiteit, en vervolgens universitair Nederland geprobeerd te hervormen en we zijn al bezig met Europa. Akke Visser en jij zullen vandaag en morgen met WISER beginnen de wereld te veranderen, ik ben benieuwd wat er volgt! Met Ineke Klinge deel ik intensieve Europese onderzoekservaringen, eerst met de Gender Impact Studie van het Vijfde 
Kader Programma, nu met het Europese Genderbasic als het voorlopig laatste project, dat jij tot zo'n succes hebt gemaakt. Ik kan hier nog net vertellen dat Genderbasic met 39 andere projecten uit alle FP6 projecten is geselecteerd om te worden opgenomen in een catalogus van FP6 Success Stories. Het maakt duidelijk dat onze principiële stellingname, namelijk dat bij alle aandacht voor kwantiteit ook altijd aandacht moet blijven voor kwaliteit, terrein wint. Niet alleen 'meer vrouwen in', maar ook beter, gender- en diversiteitsbewust onderzoek blijft derhalve ons devies! Agnes Andeweg kan hier helaas niet zijn, omdat zij misschien wel juist vandaag bevalt. Lies Wesseling en zij laten zien dat geleerde moeders de inspirerendste collega's kunnen zijn. Met Ineke Boerefijn, Catharina Eijs, Michele Vanlangenaeker, Wilma Lieben, Roel van den Oever, Aagje Swinnen en Josje Weusten is het goed toeven, zelfs op de tweede verdieping van het Soirongebouw. Meer op een afstand zijn mijn collega-genderhistorici in binnen- en buitenland, de vrouwen van het IIAV, de redactieleden van L'Homme en mijn medebestuursleden van het EPWS. Het is fijn dat velen van jullie hier aanwezig zijn.

Ten laatste dank ik mijn dierbaren: mijn moeder die met zoveel belangstelling en liefde mijn ontwikkeling heeft gevolgd, heel lang met, maar helaas ook al weer heel lang zonder vader; en mijn dierbare vrienden en vriendinnen (voorzover al niet genoemd): Norbert, Sabine, Marianne B., Ri-Jeanne, Mirian, Anna, Annemiek, Christophe, Benno, Nanno, Chris, Angelique, Nicoline, Johan, Veronie, Gemma, Kees, Lenie, Margriet, Ernestine, Flor. En dan Jo; je zegt altijd: achter iedere grote vrouw staat een grote vrouw. Ik ben bevoorrecht dat ik achter jou mag staan, of nog beter - het is per slot Werelddierendag vandaag - achter jou en Koba. Jullie zijn mijn allergrootste passie. Ik heb gezegd. (En dan nu: een lied!) 


\section{Noten}

1 Er bestaat een gedrukte versie van een deel van de liederen die waarschijnlijk tijdens de avond is uitgedeeld. In het verslag van de conferentie is een uitgebreidere, volledig drietalige versie afgedrukt. Zie Fourth Conference of the International Federation of University Women at Amsterdam July 28-August 2, 1926. z.p. In het archief van Westerdijk bevinden zich de oorspronkelijke potloodtekeningen van de Paula Rooseboom, die in het Report wordt aangeduid als architect. IIAV-Archief Johanna Westerdijk, inv. nr. 34. 'University women' zijn natuurlijk niet per definitie 'vrouwelijke wetenschappers', maar de eerste presidenten van de IFUW zijn allen hoogleraren en vooraanstaande onderzoekers in hun vak. Het 'One million dollar fund', dat ook op de tekening van de 'Marsch der University Women' is afgebeeld, is een verwijzing naar de oprichting van dit fonds door de IFUW. Het was bedoeld voor postacademische studie in het buitenland.

2 Berteke Waaldijk en Andrea Petö wijzen op het belang van dit soort feministische genealogie in hun inleiding tot Teaching with memories. European Women's Histories in International and Interdisciplinary Classrooms. Galway: Women's Studies Centre, National University of Ireland, 2004. Verg. Maria Grever (1997) 'The Pantheon of Feminist Culture: Women's Movements and the Organization of Memory,' Gender and History, 9/2, 364-374.

3 Christine de Pisan (1984) Het boek van de stad der vrouwen. Vert. uit het Middel-Frans en ingel. door Tine Ponfoort. Amsterdam: Sara.

4 Mineke Bosch (1994) Het geslacht van de wetenschap. Vrouwen en hoger onderwijs in Nederland, 1878-1948. Amsterdam: SUA, hoofdstuk 11. Het zou kunnen zijn dat de Amsterdamse vrouwelijk artsen door Westerdijks genealogie van de geleerde vrouw werden geïnspireerd tot de operette Mannen Taboe, die in 1927 bij de benoeming van Cornelia de Lange tot gewoon hoogleraar Kindergeneeskunde aan de Gemeentelijke Universiteit van Amsterdam werd opgevoerd. De voorbereidingen leidden tot een netwerk van vrouwelijke artsen, eerst in Amsterdam, later in heel Nederland, de nog steeds bestaande Vereniging van Nederlandse Vrouwelijke Artsen.

5 Zie: Mineke Bosch, 'Werken en feesten. Het archief van Johanna Westerdijk in het IIAV', in Nederlands Archievenblad. Themanummer Vrouwen en archieven. 110/7, 2006.

6 Een rode draad in al dat onderzoek is onder andere aandacht voor de onofficiële betekenispraktijken tijdens 'social events' op jaarvergaderingen en internationale congressen. Zie Mineke Bosch, met Annemarie Kloosterman (1994) Politics and Friendship. Letters from the International Woman Suffrage Alliance, 1902-1943. Columbus: Ohio State University Press.

7 Fourth Conference, 1926, 14.

8 Johanna Westerdijk en Theodora Bosanquet, 'Status of women, Memorandum presented by the International Federation of University Women to the SecretaryGeneral of the League of Nations for Submission to the Sixteenth Assembly (Sept. 1935)', 
Mededeelingen van de VVAO, 6/3 (1935), 8.

9 Marjan Tjaden, regie, The Mind has No Sex. Documentaire gemaakt in het kader van het ESF-Equal Project Genderkloof Nederlandse Universiteiten. Het befaamde MIT-report is verkrijgbaar als een speciale editie van MIT Faculty News, 11/4 (March 1999): 'A study on the Status of Women Faculty in Science at MIT', http://web.mit.edu/fnl/women/fnl114X. pdf, geraadpleegd op 27 oktober 2007.

10 Elma Drayer (1999) 'Anneke Levelt Sengers. Interview', in Mineke Bosch, ed. In het hart van de wetenschap. Naar Total E-quality en diversiteit in de universiteit. Den Haag: Sdu, $39-43$.

11 Al wordt tegenwoordig om redenen van privacy het hebben van kinderen niet meer gedocumenteerd. Zie voor een historische analyse van de statistieken van gestudeerde vrouwen in Nederland: Bosch, Het geslacht, hoofdstuk 1.

12 Alice S. Rossi (1965) 'Women in Science: Why So Few?', in Science, 148, 1196-1202.

13 Ben A. Barres (2006) 'Does gender matter?' Commentary, in Nature, vol 442, 13 juli 2006, 133-136. Zijn verhaal draaide om de geslachtsverandering die hij had ondergaan, en die hem in staat stelde om als ooggetuige te kunnen zeggen hoezeer hij als vrouw was ondergewaardeerd, en als man serieus was genomen. In Nature!

14 Lawrence H. Summers (2005) 'Remarks at NBER Conference on Diversifying the Science \& Engineering Workforce'. Cambridge, Mass. January 14, 2005. http://www.president. harvard.edu/speeches/2005/nber.html, geraadpleegd op 24 augustus 2007.

15 In Nederland wijdde Robbert Dijkgraaf er nog geen drie weken later in de NRC een column aan: Robbert Dijkgraaf (2005) 'Seks in Harvard', NRC Handelsblad, 6 februari.

16 Stephen Jay Gould (1996) The Mismeasure of Man. New York: W.W. Norton \& Company.

17 Rosalind Barnett en Caryl Rivers (2004) Same Difference. New York: Basic Books.

18 Dirk van Delft tekende de uitspraak over de rol van testosteron op uit de mond van de toenmalige voorzitter van NWO, Reinder van Duinen. Dirk van Delft (1998) 'Aandeel vrouwen in top Nederlandse wetenschap is zeer gering', in: NRC Handelsblad, 19 december 1998.

19 Marjan Tjaden, regie, Verlies van Talent. Documentaire uitgezonden in de serie Noorderlicht, VPRO, 12 februari, 1998.

20 Lies Wesseling (2001) Geleerde moeders. Amsterdam: De Balie.

21 O.a. C.A. Hawkins en B. van Balen, 'De positie van vrouwen in het wetenschappelijk onderwijs van 1970-1980', in Universiteit en Hogeschool 30 (1984), 194-209; Bosch, red. In het hart van de wetenschap, 50-51.

22 European Commission (2000). (Mary Osborn, chair, Teresa Rees, rapporteur, Mineke Bosch a.o.) Science Policies in the European Union. Promoting Excellence Trough Mainstreaming Gender Equality. A report from the ETAN Expert Group on Women and Science. Luxembourg: Office for Official Publications of the European Communities. (ETAN-rapport)

23 Anne Sayre (1975) Rosalind Franklin and DNA. New York: W.W. Norton \& Company. 
24 Christine Wennerås en Agnes Wold (1997) 'Nepotism and sexism in peer-review. Commentary', in Nature, 22.

25 Nader onderzoek heeft enerzijds uitgewezen dat de uitkomsten van het Natureonderzoek voor andere instellingen niet of niet zondermeer konden worden bevestigd, maar anderzijds werden ook diverse andere ongerechtigheden vastgesteld, bijvoorbeeld dat relatief geringere hoeveelheden geld aan vrouwen werden uitgekeerd. Zie ETANrapport: hoofdstuk 4: Fairness and Funding/Modernising peer review.

26 Zie bijvoorbeeld: Margo Brouns en Monika Scholten, Kwaliteit van het oordeel. Een onderzoek naar beoordelings-procedures naar KNAW en NWO. Uitgebracht door het NGV Utrecht, 1999. Voor de effecten van dit onderzoek in Nederland, zie: Mineke Bosch (1998) 'Naar een deltaplan voor total E-quality en diversiteit in de universiteit?', in Tijdschrift voor Genderstudies 1/4, 46-54.

27 Virginia Woolf (1958) Een kamer voor jezelf. Amsterdam. (Oorspr. A room of one's own, 1929)

28 Het is de eerste zin van het tweede deel. Simone de Beauvoir (1972) De tweede sekse. I: Feiten en mythen, II: Geleefde werkelijkheid. Utrecht (3e en 4e druk). (Oorspr. Le deuxième sexe. I, II, 1949)

29 Ik maakte zelf in 1977 kennis met 'seksismekritiek' in het onvergetelijke werkcollege 'Het seksistisch paradigma in de wijsbegeerte', van de analytisch-filosofe Else Barth aan de Rijks Universiteit Groningen.

30 Een paradigmatisch artikel, zeker onder historici, was Joan Wallach Scott (1986) 'Gender: a Useful category of Historical Analysis', in American Historical Review, 91/5, later herdrukt in Joan Wallach Scott (1988) Gender and the Politics of History. New York: Columbia University Press, 28-50. In mijn uitleg hier gebruik ik net even een andere ordening dan die Scott aanbrengt.

31 Mineke Bosch (2006) Curious Careers. An Unexpected History of Women in Science and Technology. Eindhoven: Foundation for the History of Technology, 55.

32 Margaret W. Rossiter (1984) Women Scientists in America: Struggles and Strategies to 1940. Baltimore/Londen: Johns Hopkins University Press. (4e druk); Margaret Rossiter (1995) Women Scientists in America. Before Affirmative Action, 1940-1972. Baltimore en Londen, The Johns Hopkins University Press, 1995. Het derde deel is in de maak. Rossiter won diverse prijzen voor haar werk. Sinds 1987 is er een prijs naar haar vernoemd, The Margaret W. Rossiter History of Women in Science Prize, die wordt uitgereikt door The History of Science Society.

33 Londa Schiebinger, The Mind Has No Sex? Women in the Origins of Modern Science. Cambridge, Ma., Harvard University Press, 1988; Phillips, Patricia, The Scientific Lady. A Social History of Women's Scientific Interests: 1520-1918. Londen: Weidenfeld \& Nicolson, 1990; voor Nederland: Bosch, Mineke, 'Kies Exact! In historisch perspectief: veranderende visies op meisjesonderwijs en de exacte vakken, 1650-1880', in ' $Z$ ij is toch wel zeer begaafd.' Historische bijdragen over vrouwen in de bètawetenschappen. 
(red. Annemarie de Knecht-van Eekelen en Ida Stamhuis). Themanummer van Gewina. Tijdschrift voor de geschiedenis der geneeskunde, Natuurwetenschappen, Wiskunde en Techniek, 20/4 (1997), 184-210.

34 Margaret W. Rossiter (1993) 'The [Matthew] Matilda Effect in Science', in Social Studies of Science, 23, 325-341.

35 Bosch, Het geslacht van de wetenschap, hoofdstuk 12.

36 Pnina G. Abir-Am en Dorinda Outram (red.), Uneasy Careers and Intimate Lives. Women in Science 1789-1979. With a foreword by Margaret W. Rossiter. New Brunswick/Londen: Routledge, 1987; Helena M. Pycior, Nancy G. Slack en Pnina Abir-Am, eds. (1996) Creative Couples in the Sciences. New Brunswick: Rutgers University Press.

37 Te denken valt aan de koppels Mileva Einstein Maríc en Albert Einstein, Georg Hoyt Wipple en Friede Robsheit Robbins, en Lise Meitner en Otto Hahn. Zie Hilary Rose (1994) 'Nine Decades, Nine Women, Ten Nobel prizes: Gender Politics at the Apex of Science', in Idem, Power and Knowledge. Towards a feminist transformation of the sciences. Cambridge, Polity Press, 136-170.

38 Rentetzi, Maria (2004) 'Introduction: Women Pioneers in Radioactivity research', in Sona Štrbánová, Ida Stamhuis and Katerina Mojsejová, eds. Women Scholars and Institutions. Proceedings of the International Conference (Prague, June 8-11, 2003). Prague: Research Centre for the History of Sciences and the Humanities founded by the Academy of Sciences of the Czech Republic and the Charles University 2004, 581-589.

39 Een iets andere benadering is die van de parallelle levens, of de meervoudige biografie, door Barbara Henkes met succes toegepast op vier volkskundigen in Nederland: Barbara Henkes (2005) Uit liefde voor het volk. Volkskundigen op zoek naar de Nederlandse identiteit, 1918-1948. Amsterdam: Atheneum, Polak en Van Gennep. Verg ook: Corrie van Eijl, Barbara Henkes e.a., eds. Parallelle Levens. Jaarboek voor Vrouwengeschiedenis 18. Amsterdam: Stichting Beheer IISG.

40 Carolyn Merchant (1980) The Death of Nature: Women, Ecology and the Scientific Revolution. San Francisco: Brian Easlea (1981) Science and sexual Oppression. Londen, Weidenfeld and Nicholson.

41 Evelyn Fox Keller (1987) Een wereld van verschil. Beschouwingen over sekse en wetenschap. Amsterdam: Meulenhoff. (Oorspr. Reflections on Gender and Science, 1985); Londa Schiebinger (1993) Nature's Body. Sexual Politics and the Making of Modern Science. Londen: Pandora.

42 Haraway heeft deze retoriek wel verder onderzocht, want het samengaan van manliness en modesty ligt niet zondermeer voor de hand. Het eigentijdse debat over haec vir, hic mulier blijkt daarin een rol te spelen. Zie Donna J. Haraway (1997) Modest Witness@Second_Millennium.FemaleMan@_Meets_OncoMouseTM. Feminism and Technoscience. New York/Londen: Routledge. Zij baseert zich daarbij op Elizabeth Potter, die in 2001 haar onderzoek naar het verband tussen opvattingen over gender en klasse en de wetten van Boyle publiceerde: Gender and Boyle's Law of Gases. Bloomington and 
Indianapolis: Indiana University Press.

43 Brian Easlea (1983) Fathering the Unthinkable. Masculinity, scientists and the arms race. Londen: Pluto.

44 Simon Schaffer en Steven Shapin (1985) Leviathan and the Air-pump: Hobbes, Boyle, and the experimental life. Princeton: Princeton University Press. Shapin en Schaffer ontvingen in 2005 voor hun werk de Nederlandse Erasmusprijs.

45 Steven Shapin (1994) A social history of truth: civility and science in seventeenth-century England. Chicago: University of Chicago Press. Zie ook Lorraine Daston en H. Otto Sibum, eds. (2003) Scientific Personae and their Histories. Special issue Science in Context, 16/12.

46 Jan Golinski (2002) 'The Care of the Self and the Masculine Birth of Science', in History of Science, 125-145.

47 Steven Shapin and Christopher Lawrence (1998) 'The Body of Knowledge', in Shapin and Lawrence, eds. Science Incarnate. Historical Embodiments of Natural Knowledge. Chicago \& Londen: The University of Chicago Press, 1-19. In deze bundel ook: Janet Browne, 'I could have retched all night. Charles Darwin and his body', 240-287. Kary Mullis (1998) Dancing Naked in the Mine Field. New York: Pantheon Books.

48 Zie voor publieke beelden van wetenschap: Marcel C. Lafollette (1990) Making Science Our Own. Public images of science, 1910-1955. Chicago/Londen: The University of Chicago Press.

49 Elisabeth Wesseling (2004) 'Judith Rich Harris: The Miss Marple of Developmental Psychology', in Science in Context, 17/3. De ironie wil dat Larry Summers in zijn vermaledijde optreden zelfs naar Harris verwees bij zijn bewering dat genetisch bepaald gedrag belangrijker is dan opvoeding door de ouders om de ondervertegenwoordiging van vrouwen in de natuurwetenschappen te verklaren.

50 Bosch, In het hart van de wetenschap, 486-487, noot 14, voor een bespreking van de necrologie als een belangrijk tekstgenre voor de constructie van sekse, maar ook van 'professionaliteit'. Alle drie de biografische portretten in het boek begon ik daarom met een uiteenzetting van de overlevering over de vrouw in kwestie. Bosch, In het hart van de wetenschap, 157-164, 269-273, 391-194.

51 Pierre Nora (1989) 'Between Memory and History', in Representations, 26/1, 7-26. Ook in Nederland werd een vierdelige serie Plaatsen van herinnering uitgebracht onder redactie van vier verschillende teams. H.L. Wesseling schreef een inleiding bij deze reeks: Plaatsen van herinnering. Een historisch succesverhaal. Amsterdam: Bert Bakker, 2005.

52 Een mooie inleiding geeft Maria Grever (2004) 'Visualisering en collectieve herinneringen. "Volendams meisje" als icoon van nationale identiteit', in Tijdschrift voor Geschiedenis, 117/2, 207-229. Een algemene introductie is Peter Fritzsche (2001) 'The case of modern memory', in Journal of Modern History, 73, 87-117.

53 Jos Perry (1999) Wij herdenken, dus wij bestaan: over jubilea, monumenten en de 
collectieve herinnering. Nijmegen: SUN.

54 De eerste systematische reflectie hierop is: Pnina G. Abir-Am en Clark A. Elliott, eds. (1999) Commemorative Practices in Science: Historical Perspectives on the Politics of Collective Memory. Osiris. Second series, 14.

55 Thomas Söderqvist (2007) 'A New look at the genre of Scientific Biography', in Idem, ed. The History and Poetics of Scientific Biography. Aldershot: Ashgate, 1-15.

56 Uitzonderingen zijn: Michael Shortland en Richard Yeo (1996) Telling Lives in Science. Essays onsscientific Biography. Cambridge: Cambridge University Press. En Frank Huisman, Cathrien Santing en Bert Theunissen, eds. (2000) De biografie als genre in de wetenschapsgeschiedenis. Themanummer van Gewina. Tijdschrift voor de geschiedenis der geneeskunde, Natuurwetenschappen, Wiskunde en Techniek 23 (2000). Rotterdam: Erasmus Publishing.

57 Zie mijn inleiding in Mineke Bosch (2005) Een onwrikbaar geloof in rechtvaardigheid. Aletta Jacobs, 1854-1929. Amsterdam: Balans; Mineke Bosch (2007) 'Van "bijzonder mens" tot "abnormale vrouw": psychoanalyse, gender en de biografie', in Bindels en Van Meilck, eds. Oude levens, nieuwe kwesties. Roermond: Huis voor de Kunsten Limburg, 101-115, en Mineke Bosch (2007) 'Het persoonlijke is politiek: dilemma's van gelijke behandeling in de biografie', in J.W. Renders en G. Voerman, eds., Privé in de politieke biografie. Amsterdam: Boom, 2007.

58 Maaike Meijer (1996) In tekst gevat: inleiding tot een kritiek van representatie. Amsterdam: Amsterdam University Press, 33.

59 Zie bijvoorbeeld: Greta Noordenbos (2003) Marie \& Irène Curie: de eerste vrouwelijke Nobelprijswinnaars. Delft: Eburon.

60 Helena M. Pycior (1996) 'Pierre Curie and "His Eminent Collaborator Mme Curie": Complementary Partners', in Pycior, Slack en Abir-Am, Creative Couples, 39-56.

61 Helena M. Pycior (1993) 'Reaping the benefits of collaboration while avoiding its pitfalls: Marie Curie's rise to scientific prominence', in Social Studies of Science, 23, 301-323.

62 Respectievelijk http://www.radon-info.de/Images/marie_curie.gif; http://www. khoahoc.com.vn/photos/Image/2005/11/07/Marie-Peirre-Curie.jpg; http://www. universalis.fr/corpus-encyclopedie/130/p151851/encyclopedie/radium.htm; geraadpleegd 17 september 2007.

63 De eerste tekening heb ik niet meer kunnen vinden, maar ook in september 2007 van het web geplukt. De tweede tekening staat bijna paginagroot afgebeeld in: Jack Meadows (1997) De geschiedenis van de wetenschap. Samengevat in de spectaculaire levens van twaalf geleerden. Beek: Uniepers Abcoude, p. 199. Ik herinner mij dat Ida Stamhuis de afbeelding ook ooit heeft laten zien als een voorbeeld van het Matilda-effect.

64 Astrid Schürmann (2004) 'Promoting international women's research on radioactivity: Marie Curie's laboratory', in Sona Strbávová, Ida Stamhuis and Katerina Mojsejová, eds. Women Scholars and Institutions. Proceedings of the International Conference (Prague, June 8-11, 2003). Prague: Research Centre for the History of Sciences and the Humanities 
founded by the Academy of Sciences of the Czech Republic and the Charles University 2004, 591-605.

65 James Watson (1970) The double helix. A personal account of the discovery of DNA. Harmondsworth: Penguin Books. Ik las dit boek tijdens mijn kortstondige studie scheikunde in het academisch jaar 1972-1973, of vlak daarna.

66 Dat zij een positief voorbeeld is geworden voor vrouwen in de natuurwetenschappen en daarbuiten kan bijvoorbeeld blijken uit het feit dat een bijzonder effectief, op vrouwen gericht fellowship-programma aan de RU Groningen naar haar is genoemd. Op de Website wordt het doel van dit programma omschreven als: 'To promote the participation of women in Liberal Arts and Natural Sciences, the University of Groningen offers a prestigious fellowship programme, named after Rosalind Franklin, a brilliant British chemist whose research -unique in her approach at the time-made an important contribution to the discovery of the structure of DNA. With this Fellowship the University of Groningen attracts female scientist with a special area of expertise. They will be given the opportunity to establish their own line of research, eventually receiving a full professorship through Tenure Track.'

67 Wiel Hoekstra (2001) 'Eerherstel', in Academische Boekengids, 26 (april 2001).

68 Editorial Review Amazon.com door Therese Littleton. http://www.amazon.com/DoubleHelix-Personal-Discovery-Structure/dp/0451627873, geraadpleegd 28 augustus 2007.

69 Watson, The double helix, 25.

70 'There was not a trace of warmth or frivolity in her words. And yet I could not regard her as totally uninteresting. Momentarily I wondered how she would look if she took off her glasses and did something novel with her hair.' Watson, The double helix, 61 (mijn vertaling).

71 Watson, The double helix, 25-26.

72 Ibid, 27.

73 Sayre, Rosalind Franklin, 21; in de biografie van Brenda Maddox zijn twee foto's van Franklin waarop zij een bril draagt, maar zij draagt er geen op de vele andere. Brenda Maddox (2002) Rosalind Franklin. The Dark Lady of DNA. Londen: Harper and Collins.

74 Londa Schiebinger (1999) Has Feminism Changed Science? Cambridge, Londen: Harvard University Press, 77. Zie ook: Anne Heisenberg (1992) 'Women and the Discourse of Science', in Scientific American, July 1992, 122.

75 Naar Maddox suggereert zou het goed kunnen zijn dat hij zijn boek zelfs voor een deel heeft gemodelleerd naar Kingsly Amis' debuut Lucky Jim uit 1954, de roman - die al in 1957 werd verfilmd - over een aanvankelijk uiterst onbeholpen universitair docent die uiteindelijk op zijn pootjes terechtkomt. Franklin zou dan lijken op een van zijn tegenspelers, de onflatteuze en ongelukkige Margaret Peel, die zelfmoord pleegt. Maddox baseert zich daarbij op de eerdere titel van het manuscript 'Honest Jim', naar een bijnaam die hij kreeg van de collega's van Franklin in King's College. Ze maakt aannemelijk dat Watson altijd blijk heeft gegeven van schuldgevoelens over de wijze 
waarop zij de ontdekking hadden geclaimd. Zie Maddox, The Dark Lady, 311-321.

76 Zo eindigt Wiel Hoekstra zijn artikeltje over eerherstel voor Franklin met naar haar te verwijzen als 'een moeilijke, maar wetenschappelijk hoogstaande vrouw'.

77 Cornelia de Lange (1949) 'De vrouwelijke artsen in Nederland', in Gedenkboek van de Koninklijke Nederlandsche Maatschappij tot Bevordering van de Geneeskunst. Ter gelegenheid van het honderd-jarig bestaan, 7-8-9 juli 1949. Amsterdam: J.H. de Bussy, 210.

78 Universiteitsmuseum Utrecht, Archief Tentoonstelling 'Blauwkous?'.

79 Mijn interpretatie van de wijze waarop Ornstein met zijn vrouwelijke studenten en assistenten omsprong is een andere dan naar voren gebracht door: Ida Stamhuis en Marianne I.C. Offereins (1997) 'Twee vrouwelijke natuurkundigen en hun promotor in het Interbellum: Lili Bleeker, Truus Eymers en Leonard Ornstein', in Ida H. Stamhuis en Anne-Marie de Knecht-van Eekelen, ed. 'Zy is toch wel zeer begaafd.' Historische bijdragen over vrouwen in de bètawetenschappen. Themanummer van Gewina. Tijdschrift voor de geschiedenis der geneeskunde, Natuurwetenschappen, Wiskunde en Techniek, 20/4, 256-268. Ik baseer mij daarbij voor een deel op dezelfde bronnen als worden genoemd in het artikel, en op Leo Molenaar (2003) De rok van het universum. Marcel Minnaert, astrofysicus, 1893-1970. Amsterdam: Balans.

80 Zij ontketenden in de jaren dertig een polemiek met hun artikeltje 'Naar de beroepsarbeid van de gehuwde vrouw', in Vrouw en Gemeenschap, 3/7 (dec. 1932): 'Wij moeten voor de getrouwde vrouw de vrijheid veroveren beroepsarbeid te beoefenen! Want die vrijheid heeft zij tans niet. Wij bedoelen niet alleen de dreigende crisismaatregelen of de nog bestaande gebreken der wetgeving. Maar wij bedoelen vooral de dwang die ontstaat door de traditie en de economiese factoren, een dwang die vele malen erger is dan de wettelike, en waardoor het bedroevend kleine percentage vrouwen in alle beroepen te verklaren is.' Molenaar heeft deze artikelen niet gezien, maar hij wijst wel op de tegenstrijdige manier waarop Minnaert het leven van Marie en Pierre Curie schetst (p. 211-212). Zie ook Bosch, Het geslacht van de wetenschap, 352, 532

81 Christine van Broeckhoven (2007) Brein en branie. Een pionier in Alzheimer. Antwerpen: Houtekiet, p. 170.

82 Verg. Mineke Bosch (2002) 'Women and Science in the Netherlands: a Dutch Case?', in Science in Context, 15/4, 514 .

83 Marita Mathijsen, 'De letterkunde en de vrouw', in NRC Handelsblad, 15/16 september 2007.

84 Natuurlijk zijn er gunstige uitzonderingen. De UU heeft een geschiedenissite waarop vrouwelijke wetenschappers een zichtbare rol vervullen.

85 Annet Mooij (2006) De strijd om de Februaristaking. Amsterdam: Balans.

86 www.helsinki.fi/akka-info/tiedenaiset/, geraadpleegd 15 oktober 2007. 
